San Jose State University

SJSU ScholarWorks

Master's Theses

Master's Theses and Graduate Research

Spring 2011

\title{
Post-fire analysis of Sequoia sempervirens forests on the central coast of California
}

Rachel Anne Lazzeri-Aerts

San Jose State University

Follow this and additional works at: https://scholarworks.sjsu.edu/etd_theses

\section{Recommended Citation}

Lazzeri-Aerts, Rachel Anne, "Post-fire analysis of Sequoia sempervirens forests on the central coast of California" (2011). Master's Theses. 3938.

DOI: https://doi.org/10.31979/etd.7vkb-pjep

https://scholarworks.sjsu.edu/etd_theses/3938

This Thesis is brought to you for free and open access by the Master's Theses and Graduate Research at SJSU ScholarWorks. It has been accepted for inclusion in Master's Theses by an authorized administrator of SJSU ScholarWorks. For more information, please contact scholarworks@sjsu.edu. 
POST-FIRE ANALYSIS OF SEQUOIA SEMPERVIRENS FORESTS ON THE CENTRAL COAST OF CALIFORNIA

\author{
A Thesis \\ Presented to \\ The Faculty of the Department of Environmental Studies \\ San Jose State University \\ In Partial Fulfillment \\ of the Requirements for the Degree \\ Master of Science
}

by

Rachel Anne Lazzeri-Aerts

May 2011 
(C) 2011

Rachel Anne Lazzeri-Aerts

ALL RIGHTS RESERVED 
The Designated Thesis Committee Approves the Thesis Titled

POST-FIRE ANALYSIS OF SEQUOIA SEMPERVIRENS FORESTS ON THE CENTRAL COAST OF CALIFORNIA

by

Rachel Anne Lazzeri-Aerts

APPROVED FOR THE DEPARTMENT OF ENVIRONMENTAL STUDIES

SAN JOSÉ STATE UNIVERSITY

May 2011

Dr. Will Russell

Department of Environmental Studies

Dr. Rachel O’Malley

Department of Environmental Studies

Dr. Lynne Trulio

Department of Environmental Studies 


\section{ABSTRACT \\ POST-FIRE ANALYSIS OF SEQUOIA SEMPERVIRENS FORESTS ON THE CENTRAL COAST OF CALIFORNIA}

by Rachel Anne Lazzeri-Aerts

The public perception of wildfire is that it destroys forests and that all fires should be quickly extinguished. However, fire plays a central role in determining structure, composition, and recruitment in many forest types. In coast redwood forests, the role of fire is not well understood, particularly in the southern part of the range. Observational data suggest that redwoods are relatively unaffected by fire. The sites of three 2008 and 2009 fires were sampled for this study: the Martin Fire in Bonny Doon, California, the Whitehurst Fire near Gilroy, California, and the Lockheed Fire near Swanton, California. Randomly selected ten-meter diameter plots were used to collect data on survivorship and post fire regeneration in order to determine the short-term response of Sequoia sempervirens to fire. Additionally, data were collected on associated tree species in order to compare mortality and regeneration between adjacent forest types. Data collected included mortality, tree height, diameter at breast height, scorch height, percent residual and regenerated canopy cover by species, and the number of basal spouts and seedlings by species. Results indicate that $S$. sempervirens had the lowest mortality levels, highest crown survival, and greatest regeneration, including canopy regeneration, basal sprouting, and seedling growth of all the species studied. Redwood basal sprouts and redwood seedlings far outnumbered those of associated tree species. However, there was great variability between sites. Variation may be due to differing soils, distance from the ocean, different land uses, fire severity, or a combination of factors. 


\section{ACKNOWLEDGMENTS}

I would like to thank my committee members for all of their time, advice, and valuable input during the entire thesis process. To Dr. Will Russell, thank you for pushing me to think further and make this project the best that I could, and for your constant encouragement, advice, and support. To Dr. Rachel O'Malley, thank you for keeping me on track and making statistics not so scary. To Dr. Lynne Trulio, thank you for jumping in as a last minute addition to my committee and for the valuable comments on early drafts of my thesis.

Also, a big thank you to all the volunteers who helped me with data collection in the field: Will Russell, Rick Lazzeri, Caroline Bour, Lillian Lazzeri, Ken Aerts, Lisa Benham, Nathan Hale, Gizelle Hurtado, Julianna Mandler, and Amy Peterson. I definitely would not have been able to finish this project without your help.

To the California Department of Fish and Game, Santa Clara County Parks Department, and Cal Poly, Swanton Pacific Ranch, I owe a thank you for allowing me to conduct my research on their properties.

And finally, thank you to my family, my husband Ken, my son Austin, and my parents Rick and Lillian, for all their support, encouragement, and love during this journey. 


\section{TABLE OF CONTENTS}

Introduction $\quad 1$

Literature Review 2

Ecology of Coast Redwood 2

Ecology of Associated Tree Species $\quad 5$

Land Use History $\quad 15$

$\begin{array}{lr}\text { Fire Ecology and Previous Research } & 18\end{array}$

Problem Statement and Hypothesis $\quad 24$

$\begin{array}{ll}\text { Methods } & 26\end{array}$

$\begin{array}{ll}\text { Study Sites } & 26\end{array}$

$\begin{array}{ll}\text { Plot Design } & 38\end{array}$

$\begin{array}{ll}\text { Measurements } & 39\end{array}$

$\begin{array}{ll}\text { Analysis } & 40\end{array}$

$\begin{array}{ll}\text { Limitations } & 44\end{array}$

$\begin{array}{ll}\text { Results } & 46\end{array}$

Resistance to Fire $\quad 49$

$\begin{array}{ll}\text { Post-fire Resilience } & 57\end{array}$

$\begin{array}{ll}\text { Discussion } & 67\end{array}$

$\begin{array}{ll}\text { Implications } & 71\end{array}$

$\begin{array}{ll}\text { Future Research } & 73\end{array}$

$\begin{array}{ll}\text { References } & 75\end{array}$ 


\section{FIGURES}

1. CAL FIRE map of the Martin Fire.

2. Whitehurst Fire perimeter map.

3. CAL FIRE map of the Lockheed Fire.

4. Diagram of plot design.

5. Post-fire percent composition of the five most common trees species on three sites in the Santa Cruz Mountains.

6. Percent of tree scorched for five most common tree species (mean \% +- SE) on three sites in the Santa Cruz Mountains.

7. Post-fire overall survival (mean $\%+$ - SE) of five most common tree species for three sites in the Santa Cruz Mountains.

8. Post-fire overall survival (mean $\%+$ - SE) of five most common tree species on three sites in the Santa Cruz Mountains by site.

9. Post-fire crown survival (mean $\%+-\mathrm{SE}$ ) of five most common tree species on three sites in the Santa Cruz Mountains.

10. Post-fire crown survival (mean $\%+$ - SE) of five most common tree species on three sites in the Santa Cruz Mountains by site.

11. Crown survival on plots with and without redwood trees present (mean +- SE) on three sites in the Santa Cruz Mountains.

12. Crown survival on plots with and without redwood trees present (mean $+-\mathrm{SE})$ grouped by three sites in the Santa Cruz Mountains.

13. Percent of trees with post-fire residual canopy of five most common tree species on three sites in the Santa Cruz Mountains.

14. Comparison of scorch height (mean $+-\mathrm{SE}$ ) of trees without and with residual canopy for five most common trees species on three sites in the Santa Cruz Mountains.

15. Comparison of percent scorch (mean $\%+$ - SE) on trees without and with residual canopy for the five most common tree species on three sites in the Santa Cruz Mountains. 
16. Percentage of trees with post-fire regenerated canopy of five most common tree species on three sites in the Santa Cruz Mountains.

17. Comparison of scorch height (mean +- SE) of trees without and with regenerated canopy for five most common species on three sites in the Santa Cruz Mountains.

18. Comparison of percent scorch (mean $\%+$ - SE) on trees without and with regenerated canopy for the five most common tree species on three sites in the Santa Cruz Mountains.

19. Number of post-fire basal sprouts per plot (mean +- SE) of four most common tree species on three sites in the Santa Cruz Mountains.

20. Number of post-fire basal sprouts per tree (mean $+-\mathrm{SE}$ ) of four most common tree species on three sites in the Santa Cruz Mountains.

21. Number of post-fire basal sprouts per tree (mean +- SE) of four most common tree species on three sites in the Santa Cruz Mountains by site.

22. Number of post-fire basal sprouts per tree (mean +- SE) in three size classes On three sites in the Santa Cruz Mountains.

23. Number of post-fire seedlings of five most common tree species on three 66 sites in the Santa Cruz Mountains. 


\section{TABLES}

1. Site description of the fires in the Santa Cruz Mountains.

2. Number of trees sampled on three sites in the Santa Cruz Mountains by site.

3. Comparison of mean tree height of five most common tree species with and without post-fire residual canopy on three sites in the Santa Cruz Mountains.

4. Comparison of mean DBH of five most common tree species with and without post-fire residual canopy on three sites in the Santa Cruz Mountains.

5. Comparison of mean tree height of five most common tree species with and without post-fire regenerated canopy on three sites in the Santa Cruz Mountains.

6. Comparison of mean DBH of five most common tree species with and without post-fire regenerated canopy on three sites in the Santa Cruz Mountains.

7. Total number of post-fire basal sprouts of four most common species on three sites in the Santa Cruz Mountains. Douglas fir is not included, because it does not sprout.

8. Total number of post-fire seedlings of five most common species on three sites in the Santa Cruz Mountains. 


\section{INTRODUCTION}

Disturbance events are important to ecosystem heterogeneity, and fire can be a major disturbance in many systems, including coast redwood (Sequoia sempervirens) forests. However, little is known about the effects of fire on the coast redwood forest, and research is needed on the response of coast redwood and associated species to fire, as well as research on long-term fire exclusion (Lorimer et al. 2009; Ramage, O'Hara, and Caldwell 2010).

For thousands of years Native Americans burned in and around redwood forests (Anderson 2005). Later settlers and loggers burned in redwood forests. Starting around the turn of the $20^{\text {th }}$ century, fire was excluded from coast redwood forests. Short-term and long-term effects of frequent burning followed by fire exclusion are not well understood. As more time passes, the likelihood of wildfire in redwood forests increases.

In 2008 and 2009, multiple fires burned in the Santa Cruz Mountains located along the central coast of California, which is the southern range of coast redwood. Three fires, Martin, Whitehurst, and Lockheed, were studied. These wildfires provided a unique opportunity for post-fire study in the southern redwood region.

The objectives of this research were to 1) quantify the resistance of coast redwoods and associated species in the Santa Cruz Mountains to fire, 2) quantify the resilience of coast redwoods and associated species in the Santa Cruz Mountains after fire, and 3) fill a gap in the literature regarding coast redwood forests' short-term response to fire, particularly in the southern redwood region. 


\section{LITERATURE REVIEW}

\section{Ecology of Coast Redwood}

Coast redwood (Sequoia sempervirens) is a long-lived, shade-tolerant tree found along the Pacific coast of North America from the extreme southwestern corner of Oregon to southern Monterey County in California. This long, narrow strip of redwood forests is broken into three distinct regions: northern, central, and southern. The forests in the three regions are distinct in environmental conditions such as precipitation, snow, soils, stand structure and composition, and geographic coverage.

The northern region of coast redwood runs from southern Oregon to east of Humboldt Bay. Redwood is regionally extensive, occurring from sea level to 950 meters in elevation. Metamorphic rock is the most common parent material. In winter and most of spring and fall, weather is cool and wet; precipitation can be greater than 2,500 millimeters, and snow is common. Summer is typically cool and sunny, with high fog that may persist throughout the day. Ecologically, the coast redwood forests in this region are more similar to temperate rain forests of Oregon and Washington than to southern redwood forests (Noss 2000).

The central region stretches from southern Humboldt County to northern San Francisco Bay. In this region, coast redwood is also regionally extensive. There is often a dense shrub layer, and these forests are similar ecologically and in composition to nearby Douglas fir-tanoak forests. Winter, late fall, and early spring are cool and wet. Precipitation may exceed 2,500 millimeters, but snow is uncommon. Summers are warm to hot and sunny with fog common along the coast and localized inland areas. Soil parent 
material is a mix of metamorphic, sedimentary, marine sedimentary, and alluvial rock (Noss 2000).

Stretching from Alameda to southern Monterey County, the southern coast redwood region consists of forest areas that are less continuous and smaller than those of the north and central regions. Redwood forests in this region are ecologically, compositionally, and genetically different than redwood forests of the northern and central region. Sparse shrub and ground layers are common. While winters are cool and wet, this region receives considerably less precipitation, about 1,000 millimeters, than the northern and central regions, and snow is rare. Summers are cool and foggy. In the southern extent of its range, redwoods are restricted to western and northern exposures and well-drained ravines. Elevation ranges from sea level to 740 meters, and soils are derived mainly from marine and non-marine sedimentary rock (Barbour et al. 2001; Noss 2000; Olson Jr., Roy, and Walters 1990).

Regeneration occurs from seedlings and vegetative sprouts, with sprouts growing more rapidly than seedlings. Sprouting can occur from cut stumps, root crowns, and damaged trunks (Olson Jr., Roy, and Walters 1990). Basal sprouting, also called clonal spread, has been found to be an important type of regeneration in coast redwood. One study found that on average, $59 \%$ of stems were from clonal spread with a range of 40 81\% (Douhovnikoff, Cheng, and Dodd 2004). Larger clonal groups may be better able to use resources than smaller clonal groups or single stems due to the high number of stems drawing on available resources. Additionally, if stems of a large clonal group remain connected, resources can be shared across the group benefiting all clonal stems. These 
large clonal groups may also have long-term advantages in regard to site persistence (Douhovnikoff, Cheng, and Dodd 2004).

Coast redwoods self prune lower limbs, have large lateral spreading roots, and are nearly always the dominant species within the forests that they occur (Olson Jr., Roy, and Walters 1990). As a tree grows taller, photosynthesis is reduced as the tree's physical ability to transport water from the root system to the highest leaves decreases. This reduction in photosynthesis limits the maximum height to which a tree may grow. Growing conditions such as water availability, intensity of storms, and climate and atmospheric changes may lead to trees reaching a similar physiological ceiling at varying physical heights (Koch et al. 2004).

Fog plays an important role in redwood ecology. Summer fog provides significant water input for both redwood trees and their forest associates helping to relieve drought stress. Redwood canopy acts as an interception surface, collecting moisture and providing fog drip for understory species. Loss of upper canopy redwoods can reduce water inputs due to the loss of a large interception surface (Burgess and Dawson 2004; Dawson 1998). Azevedo and Morgan (1974) found that near the Eel River in Humboldt County, fog was present 20 out of 46 observation days on a coastal site and 28 out of 46 observation days on an inland site. Fog precipitation was $173 \mathrm{~cm}$ on the coastal site and averaged $255 \mathrm{~cm}$ on the inland site. Fog appears to routinely extend at least $42 \mathrm{~km}$ inland in this region (Azevedo and Morgan 1974). There are no known quantitative studies on fog and its effect on redwoods in the southern region. 
Canopy gaps created by windthrow, tree mortality, or disease create additional resource availability, and suppressed redwood trees can respond by widening crowns, increasing height, and increasing basal sprouting (Busing and Fujimori 2002; Waring and O'Hara 2008). Gaps in the tree canopy can be created by a single tree falling, by sections of a snag falling, or by several trees falling at once. Typically, larger trees create larger gaps when they fall. Falling branches create the smallest gaps. The largest gaps are created when multiple trees fall; this can happen through landslides, or when a single tree falls then hits another causing part of all of the second tree to fall as well. Standing snags can create multiple small gaps over time as the snag breaks apart (Hunter and Parker 1993; Sousa 1984; White 1979). A study of canopy gaps in Big Basin Redwoods State Park found that, on average, slope failures generated larger gaps than other events, that half of the gaps analyzed were created by multiple events, and Douglas fir and coast redwood trees made larger gaps than madrone or tanoak (Hunter and Parker 1993). Regeneration in a canopy gap is typically small scale. The size of the gap effects regeneration in terms of light, temperature, and perimeter-to-area ratio (Sousa 1984; White 1979). In Humboldt Redwoods State Park, redwoods and other tree species grew in gaps when overstory redwood trees died. Redwood regeneration tended to occur along the gap edge, and a dense herb layer grew in the gap areas (Busing and Fujimori 2002).

\section{Ecology of Associated Tree Species}

Common forest associates of coast redwood in the Santa Cruz Mountains include Douglas fir, tanoak, and Pacific madrone (Olson Jr., Roy, and Walters 1990). Forest 
associates can potentially play an important role in mixed redwood forest communities; therefore, it is important to consider these tree species as mixed forests may react differently to environmental changes, including fire than pure redwood stands. The following section includes a brief description of 12 associated species sampled during this study: Pacific madrone, manzanita, coast chinquapin, tanoak, California wax myrtle, knobcone pine, ponderosa pine, Douglas fir, oak, willow, California nutmeg, and California bay.

\section{Pacific madrone}

Pacific madrone (Arbutus menziesii) forms a tall, straight trunk with distinctive reddish bark, ranges from 200-500 years old, and often has deep, spreading roots. It is common on western, and sometimes southern, exposures in areas where fog is usually present. This common understory tree can be found from 800-4,300 feet in soils with good drainage. Seedlings are usually not abundant, and early growth is slow, while basal sprouts are often abundant and grow rapidly in both height and crown. Madrone is moderately shade tolerant, and generally vulnerable to fire. After fire, or other damage, basal sprouts grow quickly. Pacific madrone is a member of the Ericaceae family, as is the next species: manzanita (Arctostaphylos spp.) (Keator 2002, 2009; McDonald and Tappeiner 1990; Stuart and Sawyer 2001). 


\section{Manzanita}

These species, that can grow both as trees and shrubs, are known for their purplered bark. While several local species can be found as multi-trunked trees reaching 15 to 20 feet in height, most species form large shrubs. Leaves are evergreen, elliptical, and vertically oriented. Small urn or bell shaped whitish-pink flowers turn into small reddish apple-shaped berries. The hard seeds inside the berries must pass through the digestive tract of birds or small mammals before germination can occur.

The many species of manzanita commonly hybridize and can be difficult to identify. Most of the several dozen species of manzanita (Arctostaphylos spp) are found in California, with many in the study region. The silver-leafed, or Bonny Doon, manzanita (A. silvicola) is endemic to the Sand Hills area of Santa Cruz County. Also found in the study region are heartleaf manzanita, also called the Santa Cruz manzanita (A. andersonii), hoary manzanita (A. canescens), Eastwood manzanita (A. glandulosa), glossyleaf, manzanita (A. nummularia), and woollyleaf, manzanita (A. tomentosa). Following fire Eastwood and woollyleaf manzanita sprout from burls. Glossyleaf manzanita can reproduce vegetatively from branch to ground contact, but does not sprout from a burl following fire (Keator 2002; McGraw 2004; Stuart and Sawyer 2001).

\section{Coast chinquapin}

The coast chinquapin (Chrysolepis chrysophylla), also called giant chinquapin or goldenleaf chestnut, has several growth forms, is rarely a dominant component of any 
stand, grows in a wide variety of habitats, is a minor component of many different forest and chaparral communities, and pure stands are uncommon and relatively small.

Ranging mostly in the Coast Ranges from San Luis Obispo County, California to Mason County, Washington, with elevations from sea level to 1,525 m/5,000 ft, the coast chinquapin is found in areas characterized by winter precipitation and summer drought on a wide range of soils. Trees appear to reach greatest size on nutrient deficient sites with deep soils. Squirrels, birds, and gravity spread the hard-shelled nuts that are contained in a spiny bur. Individual trees can reach 400-500 years old, with the oldest trees found on more xeric sites. The species is affected by heart-rotting fungi and seed-infesting insects.

The coast chinquapin is well adapted to frequent fires. After fire or injury, basal sprouting occurs in prolific amounts. On managed sites this sprouting often becomes a problem (McKee 1990).

\section{Tanoak}

Tanoak (Lithocarpus densiflorus) is evergreen with a long, tapered trunk, is often found as a single tree or in mixed conifer forests, and naturally reproduces from acorn seedlings and basal resprouting (Plumb and McDonald 1981). In the Santa Cruz Mountains, this understory tree grows best on humid, moist slopes on western exposures. It can be found in rough terrain, from sea level to roughly 2,000 meters in elevation. Tree form varies; may be tall with a central trunk and narrow crown, free branching with broad crowns, or more shrub-like. Tanoak grows rapidly, and can compete with other species if given equal resources (Tappeiner, McDonald, and Roy 1990). Tanoak was found to 
regenerate at relatively high rates in canopy gaps, which may play a role in allowing it to remain a component of forests dominated by a redwood overstory (Busing and Fujimori 2002).

Tanoaks are susceptible to crown, and sometimes ground, fires. Mature trees have bark 3 to 13 millimeters thick, but can still be badly burned. After fire, or other injury, sprouts grow rapidly and can become significant competitors; however, fire injuries can often lead to fungal infections (Tappeiner, McDonald, and Roy 1990). Following prescribed fire, shorter tanoak trees and tanoak trees with a smaller DBH had greater total crown damage and greater mortality (Kobziar, Moghaddas, and Stephens 2006).

Sudden oak death is a recent development in southern tanoak forests, and is particularly severe in the Santa Cruz Mountains. A three year study of sudden oak death progression found that mortality increased from 9.4\% to $25.2 \%$ (McPherson et al. 2005). Because dead trees have a lower foliar moisture content, fire could have a greater effect on sudden oak death affected tanoak stands, and to prevent crown ignitions, trees would have to have a higher crown base height (Kuljian and Varner 2010).

\section{California wax myrtle}

The California wax myrtle (Myrica californica), also called Pacific wax myrtle or bayberry, is commonly found in full sun or partial shade along the edges of closed-cone pine and redwood forest. It grows quickly with young shoots forming areas dense shrubs and narrow mature trees reaching 10-35 feet high. Glossy, dark green, lance shaped 
leaves are evergreen and edged with small teeth. Leaves have a spicy aroma that is more subtle than that of the California bay. Small bunches of wind pollinated flowers grow in the leaf axis. In late summer and fall, dark purple drupes, often appearing waxy or warty, cover trees. The wax myrtle is a nitrogen fixer (Keator 2002; Stuart and Sawyer 2001).

\section{Knobcone pine}

This closed cone pine ranges along the coast from the northern Santa Lucia Range to the Klamath Ranges and into southwestern Oregon, as well as east across the Cascade Range and Modoc Plateau. This species occurs from sea level in Santa Cruz County to 6,000 feet on Mt. Shasta. Knobcone pine flourishes in seemingly inhospitable conditions such as serpentine soils and dry rocky slopes. It is benefited by coastal fog during dry summers.

Trees have a thin crown, and trees in areas of high density often have interlocking limbs, while trees in low density areas have long low hanging limbs. Trees are highly flammable, often after a fire only scorched trunks, stems, and cones are left. Cones grow in groups of three to five, and hold seeds in tightly sealed cones that remain on the tree. After fire, most seeds quickly drop from the opened cone (Barbour 2007; Lanner 1999).

\section{Ponderosa pine}

Ponderosa pine (Pinus ponderosa) is a wide-ranging species. Ponderosa pine is not typically found in the redwood region, but in the Santa Cruz Mountains, the Pacific subspecies is found in open forests on sandy soils. The low moisture holding capacity 
and low fertility of the sandy soils favors ponderosa over other typical redwood community species. This subspecies/race has relatively long needles, cones, and seeds, and is the least cold tolerant of all the ponderosa pines. Growth rates compare well to the ponderosa pine of the Sierras, but stem density is much lower (Griffin 1964; Lanner 1999; Oliver and Ryker 1990).

Natural regeneration is sporadic, needing a favorable combination of heavy seed crop, weather, soil texture, plant competition, and seedbed conditions. Competing vegetation can be a deterrent to early survival, as well as later growth. Ponderosa reproduce most successfully after disturbances that expose bare soil and remove shade and competing plants. This species does not naturally reproduce vegetatively. Seeds are often eaten and spread by small mammals and birds.

After germination, roots grow rapidly forming a vigorous taproot. The shade intolerant trees often reach 300-600 years old, naturally self-prune at a slow rate, and are affected by many diseases and pests. As the trees age, the pyramid shaped crown broadens and become rounder. Fire easily kills seedlings and pole-sized trees, while larger trees have thick bark and are less often affected by fire (Lanner 1999; Oliver and Ryker 1990).

Douglas fir

Douglas fir (Pseudotsuga menziesii var. menziesii) is a long-lived conifer whose principal limiting factor is moisture, is often found on northern exposures, and has medium shade tolerance. Trees 500 years old are common. Germination occurs best on 
mineral soil or light litter in light shade. Older seedlings need full sunlight, and greatest height gains are made when trees are between 20-30 years old. Shallow roots often interconnect in older stands, and windthrow can occur in heavy wind and rain conditions. Self-pruning is slow due to slow decay of dead material. Although trees can recover from short periods of suppression and rapidly develop, Douglas fir does not have the ability to regenerate vegetatively. Older trees that have thick bark can usually resist ground fires, but crown fires are often fatal to trees of any age or size (Hermann and Lavender 1990).

Oak species

Within the Quercus family, there are over 20 species in California. Three species are commonly found in the Santa Cruz Mountains: coast live oak ( $Q$. agrifolia), canyon live oak (Q. chrysolepis), and interior live oak (Q. wislizenii). A fourth species, Shreve oak (Q. parvula var. shrevei), can be found in the Bonny Doon area of the Santa Cruz Mountains. Oaks share four main characteristics: 1) acorns, 2) distinctive windpollinated flowers, 3) strong wood, and 4) a life span of several decades to centuries.

Oak growth, survival, regeneration, and distribution are affected by precipitation, temperature, seasonal patterns, and light availability. While oaks can be found in many climates and in many soil types, soil moisture is highly important. Oaks are well known for their adaptability to shady conditions, but seedlings can be disadvantaged by high amounts of shade. The four oaks found in the area of this study are considered tree oaks. These evergreen oaks can be found in three habitat types: forest, woodland, and 
savannah. Environmental requirements of each species are fairly variable, and the four species can be found on a variety of soils and slopes and with a variety of water availability.

Acorns are produced from single flowers that are scattered on the tree singly or in small groups. The pollen-producing male flowers are found in groups called catkins. Oaks are wind pollinated. Once acorns have fallen, germination typically results after fall and winter rains.

Shrub oaks often have many trunks that branch near to the ground, while tree oaks typically have a large single trunk. In areas of high density, trees will grow tall and erect, and in areas of lower density, trees will grow broader with many large, spreading limbs.

The key features used to identify oaks are growth form, leaf shape, leaf color, bark texture, and acorn size and shape. Related species often share characteristics. Characteristics can have high variation within a species and even on a single tree. This variation can be caused by local conditions or genetics. Oaks frequently hybridize; there are 20 recognized hybrids of which 11 are named. Collectively, these facts often make it difficult to identify oak species (Pavlik et al. 2006).

Low intensity fires are often beneficial to oaks, increasing available nutrients, reducing competition, temporarily eliminating pests, and removing biomass to reduce the risk of severe fire. Basal and epicormic sprouting are common after low intensity fires, and some species also have the ability to sprout basally after severe fires as well (AllenDiaz, Standiford, and Jackson 2007). 


\section{Willow species}

Willows (Salix spp) are usually found as an understory tree in riparian habitats. These deciduous, fast growing, short lived, multi-trunked trees rarely become large trees, are often considered to be more of a large shrub species, and can be found in areas of high moisture. Flowers emerge before new leaves in early spring, are wind and insect pollinated, and produce many hairy seeds that are wind distributed. Leaves are linear or lance shaped. Catkins sit upright on branches. The arroyo willow (S. lasiolepis) is a widespread California native growing up to 25 feet tall with bicolored leaves. Typically taller than the arroyo willow, the red willow (S. laevigata) has spinier leaves and reddish twigs (Keator 2002, 2009; Stuart and Sawyer 2001).

\section{California nutmeg}

The California nutmeg (Torreya californica) is an uncommon understory conifer growing on diverse sites with best growth on moist sites in the redwood region. Typical specimens range from 15-90 feet in height. The tallest known tree (96 feet) is found on Swanton Pacific Ranch adjacent to the Lockheed Fire site. This shade tolerant species is often very slow growing. While the trunk is easily killed by fire, sprouts appear quickly. Instead of normal seed cones, the California nutmeg has arils, a single seed with a fleshy covering. Needles are straight, stiff, and end with a sharp spine (Stuart and Sawyer 2001). 


\section{California bay}

California bay (Umbellularia californica), also called California laurel, is a broadleaved evergreen tree ranging from Douglas County, Oregon to San Diego County, California and extending from the Pacific Coast to the Sierra Nevada Range. The species can be found in a wide range of habitats from steep slopes and exposed ridges to protected valleys and low hills, and a wide range of climates from cool, humid forests to hot, dry inland areas. California bay is most common in mixed stands and its dominance in forest types varies widely.

The fruit, called a drupe, falls from trees in late autumn or winter, and is dispersed by gravity, wind, animals, or water. Seedlings branch after reaching 2-3 years of age, and have several forms of transitional leaves. A taproot develops early, but root systems vary from widespread and deep to shallow and without a strong taproot. The growth rate of the California bay varies based on competition, soil conditions, and climate.

While the species is considered moderately shade tolerant, it is susceptible to wind throw. Sprouts can appear from the root collar, stumps, or the trunk of fallen trees. Thin bark makes the California bay vulnerable to fire. Trees rapidly sprout, however, young seedlings are less likely to sprout (Stein 1990).

\section{Land Use History}

Throughout California, Native Americas lived for roughly 12,000 years before the arrival of the Spanish (Anderson 2005). In the central coast area, the Ohlone flourished. Their territory ran from San Francisco Bay south to Point Sur, coinciding with the 
southern extent of the redwood region. Ohlone population estimates range from 7,000 to 10,000 individuals who lived in small tribelets, and spoke numerous dialects. These people utilized over 500 plant and animal species to survive. Acorns, berries, nuts, shellfish, large game species, and many others were staples of Ohlone life (Anderson 2005; Diekmann, Panich, and Striplen 2007; Kroeber 1976; Pritzker 2000). The Native Americans actively managed their surroundings, and fire was a commonly used tool. Burning was done regularly in and around the redwood forests to facilitate acorn gathering and hunting, promote edible plant growth, and reduce dead materials around settlements. Fire was used on both small and large scales (Anderson 2005; Diekmann, Panich, and Striplen 2007).

After the arrival of the Spanish in California, and later the Anglo/Americans, logging became a major industry in California. The Santa Cruz Mountains are considered the birthplace of redwood logging. The Spanish first logged in the Santa Cruz Mountains as early as the late 1700 s, by the 1830 s commercial logging had begun, and as the Gold Rush came to an end, redwood logging in the Santa Cruz Mountains was becoming a major industry. Redwood logging then moved to northern redwood forests. Timber harvest operations altered the landscape and ecosystems by removing vast stretches of trees, carving railroads into hillsides, and bringing thousands of workers into the area. Fire became a constant hazard. Fire was often used to reduce logging slash following timber harvest. In addition, accidental fires from the railroad, mills, encampments, and out of control slash fire frequently raged through the hillsides (Barbour et al. 2001; Noss 2000). 
The early $20^{\text {th }}$ century brought the beginning of organized fire suppression. As a backlash from the extensive fires of the late $19^{\text {th }}$ century, all fire was viewed as destructive to the forests. Increasing effort was applied to preventing and extinguishing fires in the Santa Cruz Mountains, as well as other parts of California and around the United States (Stephens, Martin, and Clinton 2007; Stephens and Fry 2005). Decades of fire suppression have increased the potential for devastating fire. Duff and litter collect on the forest floor and around the bases of trees. This accumulation of fuel can lead to more intense fires, especially on the uphill side of a tree (Finney and Martin 1993), that have the potential to harm even large redwoods. Additionally, high fuel accumulation in adjacent forest types can lead to more intense fires that may spread into redwood stands (Brown and Baxter 2003; Brown, Kaye, and Buckley 1999; Noss 2000). In late summer and early fall, after summer fog dissipates and before winter rains begin, duff and litter have a chance to dry out and become more flammable (Arno and Allison-Bunnell 2002; Stephens, Martin, and Clinton 2007).

Today, the redwood forests of the central coast are fragmented by roads and development, which have increased the complexity of managing fires and conducting research. Within state and county parks, nature reserves, and some private properties, redwood forests are protected. In other areas, timber harvest, recreational uses, and urban expansion continue to occur. 


\section{Fire Ecology and Previous Research}

Disturbance events promote to local ecological heterogeneity by creating patches that differ spatially and in age class. Disturbances vary in frequency, predictability, and magnitude, and can have minor to major effects on forest systems (Sousa 1984; White 1979). Fire can be a major disturbance in redwood forests.

Numerous environmental conditions can affect fire, such as slope, aspect, wind, temperature, humidity, fuel loads, ratio of dead to living fuels, ratio of fine to coarse fuels, fuel moisture content, fuel bed porosity, soil surface moisture, presence and amount of ether extractives, and the continuity of fuels (Biswell 1989; Brown and Smith 2000). Changes in any of these variables can change the spread, intensity, or behavior of fire. Fire behavior is measured by the rate of spread and growth, the intensity of the fire, and flame length (Biswell 1989; Brown and Smith 2000).

One major effect of fire on living plants is mortality, which depends on the amount of heat that a plant's tissues receive. Some tissues have a higher sensitivity to heat, such as growth tissues, and some tissues act as protection for the plant. Protection against fire includes bark thickness and chemistry, bud scales, and having sensitive tissues buried under soil. Increased mortality rates are observed when multiple parts of a plant are damaged by fire. Crown, stem, and root death can all occur during fire, and multiple factors, such as fire intensity and fire duration, can affect mortality. Vegetative regeneration can occur through epicormic sprouting, root collars and crowns, stolons, caudexes, rhizomes, bulbs or corms, and from roots (Brown and Smith 2000). Redwood 
trees may sprout epicormically along nearly the entire length of the bole, or basally from the root crown after damage, including fire (Olson Jr., Roy, and Walters 1990).

Through many years of observations and recent research, scientists know that coast redwoods tolerate, and even regenerate vigorously, after fire. However, redwoods are not considered a fire dependent species (Arno and Allison-Bunnell 2002; Olson Jr., Roy, and Walters 1990). In fact, Busing and Fujimori (2002) suggest that redwoods can regenerate and sustain forest stands without major disturbance events of any kind, including fire.

Megafossils have been used to trace the evolution and distribution of the coast redwood through the Mesozoic and early to mid Cenozoic eras. Pollen and macrofossil records have been used to trace the distribution of redwoods through the Holocene. In this period, there were changes in temperature, precipitation, and sea level that effected redwood's distribution (Noss 2000). However, scientists can only guess how the fire regime of this period affected redwoods.

The majority of previous research on fire in the redwood forests focuses on fire history and fire frequency, and a majority of that research focuses on the period of Native American occupation. During this time period, fire was frequent (Finney and Martin 1992). However, the roughly 12,000 years of Native American occupation is merely a few generations for a coast redwood forest. Little is known regarding the fire regime before Native American occupation. Before the presence of Native Americans in coastal California, fires were mainly caused by lightning, and due to the cool, mesic conditions of the region were most likely much less frequent than during Native American 
occupation (Brown and Baxter 2003; Brown, Kaye, and Buckley 1999). Using modeling, one study estimates a 135 year mean fire interval for the time before Native American occupation in the Monterey Bay region (Greenlee and Langenheim 1990).

During the Native American period fire return intervals have been estimated to range from 6 to 82 years (Brown and Baxter 2003; Brown, Kaye, and Buckley 1999; Brown and Swetnam 1994; Finney and Martin 1989; Finney and Martin 1992; Greenlee and Langenheim 1990; Stephens and Fry 2005). The frequency of fire in the redwood region was markedly reduced in the early $20^{\text {th }}$ century due to loss of Native American ignitions and the beginning of active fire suppression (Brown and Baxter 2003; Stephens and Fry 2005). One study of the southern redwood region suggests that there may be a negative relationship between fire return interval and the mesic to xeric moisture gradient (Greenlee and Langenheim 1990). Similarly, a shorter natural fire rotation was found for areas with a dry moisture regime than areas with a wet moisture regime, and drier moisture regimes are prevalent in the southern region. GIS was used to analyze the effects of several variables on fire over the entire redwood region, and a natural fire rotation (NFR), which is the time period divided by the proportion of study area burned in that time period (Agee 1996), was calculated for 1950-2003. NFR is used for large study areas. The study also found that in the southern redwood region the NFR was estimated to be 551 years, the shortest of the three regions. Overall, steep terrain had a shorter NFR than flat terrain, increases in elevation cause decreases in the NFR, and distance from the coast did not have a conclusive effect (Oneal et al. 2006). However, Brown and Baxter (2003) found that there was no significant change in fire frequencies 
along an ocean-to-inland gradient, which typically is a mesic-to-xeric gradient, in the Jackson Demonstration State Forest in Mendocino (Brown and Baxter 2003).

Although there is a relatively large amount of literature documenting fire histories and return intervals, there is little scientific information on fire behavior or the actual effects fire has on redwood trees and communities. Anecdotal reports exist, but contain no quantitative data. Two examples include the case study of the 2003 Canoe Fire in Humboldt Redwoods State Park (Scanlon 2007) and many sections of the book Fire Ecology of the Pacific Northwest (Agee 1993). Scanlon and Agee's observations suggest that size, age, and fire intensity may effect coast redwood's resistance to fire: larger, mature redwoods often survive low to moderate fires, but may perish in a high intensity fire. Smaller, younger redwood trees may perish even in low intensity fires (Agee 1993; Scanlon 2007).

These observations coincide with the results of two research papers that analyze post-fire mortality and basal regeneration in coast redwood forests. A study of prescribed fire in young ( $\sim 90$ to 120 year old) redwoods in Humboldt and Annadel State Parks found that few trees larger than 25 centimeters DBH were top killed in even the most extreme prescribed fire conditions. Of the trees that were top killed, less than $0.25 \%$ did not generate basal sprouts, and all of the trees were smaller than 15 centimeters DBH. Additionally, the study found that trees growing in clumps or rings around an old stump had higher fuel loading around the bases of tree and between trees, had increased trunk damage, had greater crown scorch, and higher rates of top killing. The authors suggest that the higher fuel loads, as well as the burning stump, results in higher heat levels, and 
that the heat is funneled upwards by the circular growth pattern (Finney and Martin 1993). The second paper took advantage of the widespread fires in June 2008 in old growth and second growth stands containing redwood and tanoak in the central and southern regions. Redwoods were found to have a higher trunk survival rate, especially in areas of higher fire severity, while tanoak was found to have a slight advantage in basal sprouting. The authors concluded that fire of any severity would increase redwood's relative abundance over tanoak (Ramage, O'Hara, and Caldwell 2010).

The bulk of the previous research on fire was conducted in the northern and central redwood regions. The redwood forests of these areas are different from redwood forests of the southern region in terms of environmental conditions, stand structure and composition, precipitation levels, and continuity. The southern region has considerably less annual precipitation than either of the other regions. Redwood forests in the northern and central regions are larger and far more continuous. Southern forests are genetically, ecologically, and compositionally different from northern and central forests: northern redwood forests are more similar to northern temperate rain forests and central redwood forests are more similar to nearby Douglas fir forests (Barbour et al. 2001; Noss 2000). Each of these variables affects the how redwoods grow, influences past and present land use, changes fire behavior, and may affect how redwoods respond to fire. Management, preservation, and restoration in turn will be different among the three regions.

While fire is not essential for redwood survival, it may be beneficial. Fire facilitates nutrient and energy cycling through the rapid chemical and physical changes that occur during a burn (Brown, Kaye, and Buckley 1999). Additionally, fires help 
recycle woody debris (Jacobs, Cole, and McBride 1985). Frequent, low intensity fires help promote open stands with low tree densities in two ways. First, young or small redwood trees are killed before reaching canopy status (Brown and Baxter 2003). Second, frequent fire reduces the opportunities for fire intolerant species to establish (Brown and Baxter 2003). On the other hand, during long intervals between fires fuel loads and tree densities can increase and ladder fuels may form, which can lead to greater intensity fire when fires do occur (Brown and Baxter 2003; Brown, Kaye, and Buckley 1999). 


\section{PROBLEM STATEMENT AND HYPOTHESIS}

In their review paper on disturbance regimes in redwood forests, Lorimer et al. (2009) state that there is a lack of research on the response of redwoods and associated species to fire, especially regarding sprouting and seeding establishment after fire. This statement is supported by the fact that there is very little published research that contains quantitative data on redwood's response to fire. Limited understanding of how coast redwoods and their forest associates respond to fire can hamper fire management, as well as conservation and restoration efforts. The objectives of this research were to 1) quantify the resistance of coast redwoods and associated species in the Santa Cruz Mountains to fire, 2) quantify the resilience of coast redwoods and associated species in the Santa Cruz Mountains after fire, and 3) fill a gap in the literature regarding coast redwood's response to fire, particularly in the southern redwood region. The specific hypotheses that this study investigated were:

1) Redwood trees are more resistant to fire than associated tree species.

a. Redwood trees are less likely than associated tree species to have overall mortality caused by fire.

b. Redwood trees are less likely than associated tree species to have crown mortality caused by fire.

c. Redwood trees are more likely to have residual canopy after fire than associated tree species. 
2) Redwood trees have different levels of resiliency after fire compared to associated tree species.

a. Redwood trees are more likely to have regenerated canopy after fire than associated tree species.

b. Redwood trees have greater basal regeneration after fire than associated tree species.

c. Redwood seedlings are less likely to germinate after fire than the seedlings of associated tree species. 


\section{METHODS}

The following section describes study sites, data collection methods, and data analysis methods. Study sites were chosen based on recent fire activity, accessibility, and safety. Each of the three sites is unique and collectively represents the varying redwood communities in the Santa Cruz Mountains. Data collection methods were chosen based on relevant literature and ease of use to facilitate consistent measurements.

\section{Study Sites}

The three study sites were in Santa Clara and Santa Cruz Counties, in the region of California known as the Central Coast (Table 1). Santa Clara County lies inland from Santa Cruz County, which is directly on the coast. Elevations range from sea level to several thousand feet, and both counties have diverse ecosystems, such as grassland, shoreline, oak woodland, chaparral, mixed evergreen, and redwood forest. Climate is considered temperate to hot, with heavy marine influence. Summer fog is common. Precipitation ranges from 16 to 60 inches, and falls nearly all as rain. Large human populations create a growing urban-wildland interface (Alexander and Sawyer 1997). The increasing presence of humans creates opportunities for accidental ignitions and puts increased pressure on firefighters to extinguish wildfires. While there have been several large wildfires in the two counties over the past century, none of the study sites have burned in at least 50 years. Data were collected on three sites that experienced fire in 2008 or 2009 in Santa Cruz and Santa Clara Counties within the Santa Cruz Mountains. 
Table 1. Site description of three fires in the Santa Cruz Mountains.

\begin{tabular}{|l|l|l|l|l|l|}
\hline Fire & Location & $\begin{array}{l}\text { Distance } \\
\text { from Ocean }\end{array}$ & Elevation & Fire Dates & $\begin{array}{l}\text { Size of Burn } \\
\text { Site }\end{array}$ \\
\hline Martin & $\begin{array}{l}\text { Bonny Doon } \\
\text { Ecological } \\
\text { Reserve }\end{array}$ & $5.75 \mathrm{~km}$ & $\begin{array}{l}365- \\
518 \mathrm{~m}\end{array}$ & $\begin{array}{l}11-15 \mathrm{June} \\
2008\end{array}$ & $210.44 \mathrm{ha}$ \\
\hline Whitehurst & $\begin{array}{l}\text { Mt. Madonna } \\
\text { County Park }\end{array}$ & $14 \mathrm{~km}$ & $\begin{array}{l}426- \\
487 \mathrm{~m}\end{array}$ & $\begin{array}{l}21-26 \text { June } \\
2008\end{array}$ & $103.6 \mathrm{ha}$ \\
\hline Lockheed & $\begin{array}{l}\text { Swanton } \\
\text { Pacific Ranch }\end{array}$ & $2.53 \mathrm{~km}$ & $\begin{array}{l}61- \\
335 \mathrm{~m}\end{array}$ & $\begin{array}{l}12-23 \text { August } \\
2009\end{array}$ & $3,163.43 \mathrm{ha}$ \\
\hline
\end{tabular}

Martin Fire

In Santa Cruz County, the Martin Fire burned 210 hectares in the Bonny Doon Ecological Reserve (BDER) from June 11-15, 2008 (Figure 1). Of the 210 ha burned, roughly 17.4 ha consisted of redwood forest. Sampling was primarily conducted in the vicinity Reggiardo and Laguna Creeks where most of the redwood occurred. Additional sampling was extended from the creek zones into upland areas where redwood existed in isolated patches in a matrix of tanoak, madrone, Douglas fir, and knobcone pine.

A large portion of the Bonny Doon Ecological Reserve contains Santa Cruz Sandhills (sandhills). The Santa Cruz Sandhills have been described as "a unique community of plant and animal species found on Zayante soils in Santa Cruz County" (McGraw 2004). Soils in the sampled areas of the Reserve include Lompico-Felton complex, Ben Lomond-Catelli-Sur complex, and Zayante course sand. The LompicoFelton complex comes from weathered from mudstone, siltstone, sandstone, shale, and/or mica schist. The Ben Lomond-Catelli-Sur complex has parent material that comes from weathered granite, sandstone, and/or schist. The Zayante course sand is consolidated marine deposits and/or weathered from sandstone (Natural Resources Conservation 
Service 2009). These small outcrops of weathered marine sediments are found between the San Lorenzo River Valley and Carbonera Creek (Soil Conservation Service 1980), but development has caused both habitat fragmentation and habitat destruction. At 48.5 hectares, the Bonny Doon Ecological Reserve is the largest remaining area of sandhills (McGraw and Levin 1998). A conservation plan prepared for the Land Trust of Santa Cruz County in 2004 designated this site as a Tier 1 site for conservation and protection. This designation results from the site having high landscape integrity, high biological value, and a large size. Stresses on the community at the BDER include fire exclusion, exotic plants, and recreation (Kluse and Doak 1999; McGraw 2004; McGraw and Levin 1998).

Information on the history of the Bonny Doon area is scarce. According to Robert Piwarzyk and Paul Tutwiler (1999) in "A Brief History of the Land Use of the Bonny Doon Ecological Reserve," the Bonny Doon area was logged in the 1850s and 1860s. In the Reserve, there was some logging along the creeks, and some of this timber may have been used to fuel local limekilns. Later, vineyards and orchards occupied the area. The Bourcq Winery was located directly across from the present day firehouse on Martin Road on land that is now part of the Reserve. Prohibition led to the end of the vineyards. A failed Christmas tree farm followed. Some minor gold exploration may have occurred along the creeks within current Reserve boundaries. The Bonny Doon Ecological Reserve was created in 1989 and is managed by the California Department of Fish and Game (DFG). 

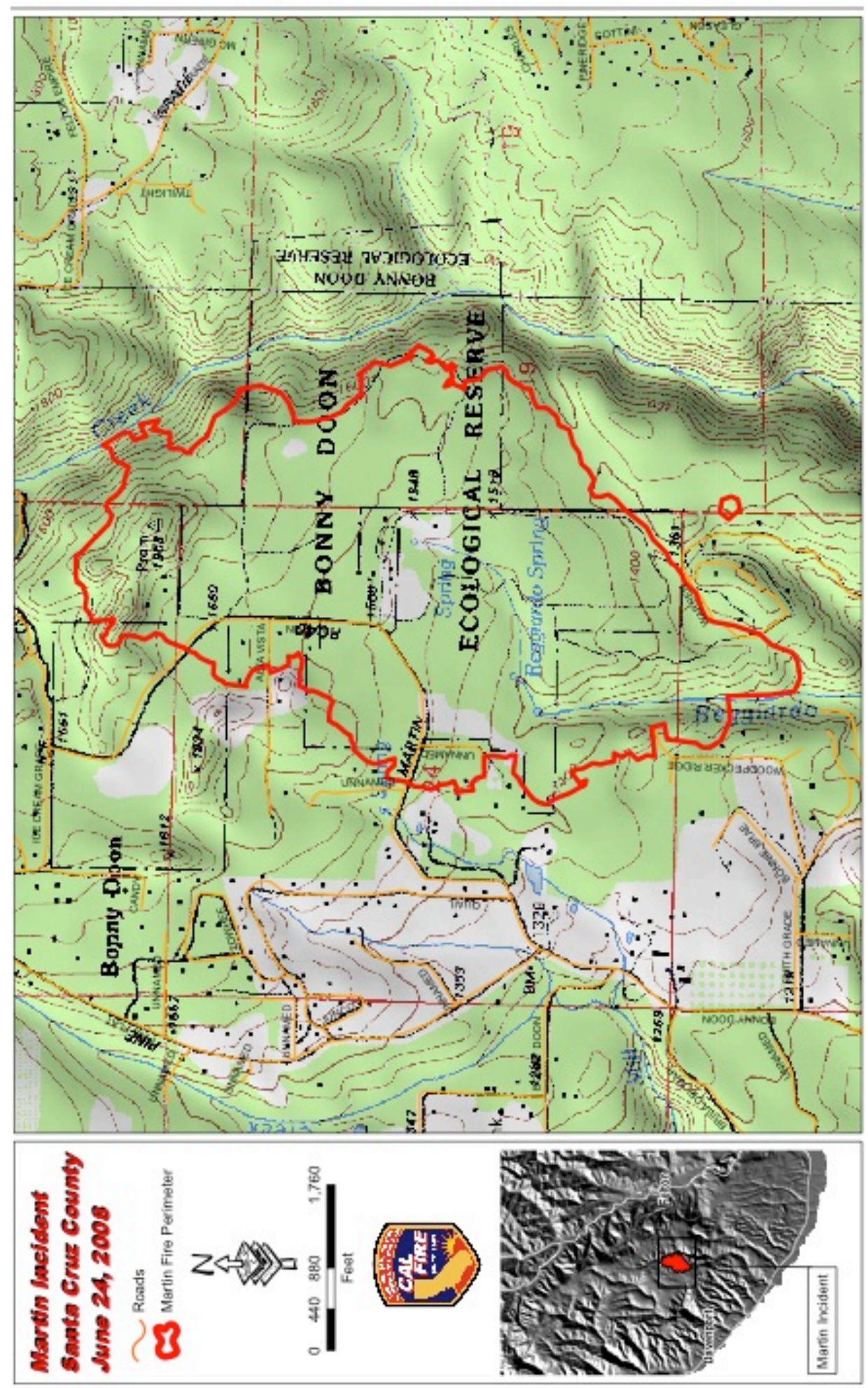

Figure 1. CAL FIRE map of the Martin Fire. Sampling for this study took place south, east, and southeast of the curve in Martin Road. Map courtesy of CAL FIRE. 
Recorded fire history within the reserve is also poorly recorded. During the logging era, occasional slash fires occurred (Squires 2008). Between the end of logging and the 1960 's, there appears to have been no fires within the reserve. In the 1960's there was a small fire that burned within today's reserve boundaries (Squires 2008). Since this fire, there have been no fires in the Bonny Doon Ecological Reserve or the immediate surrounding area. In 2004, CAL FIRE determined that the reserve had a "high potential for disastrous fire" due to high fuel loading and old stands of knobcone, ponderosa, and manzanita (CALFIRE 2004).

Between 1989 and 2006, there had been some trail clearing and minimal fuels reduction conducted by volunteers. CAL FIRE and CFG began collaborating on a Vegetation Management Plan (VMP) for the Bonny Doon Ecological Reserve. Proposed work included creating fire breaks along Martin Road and Ice Cream Grade, limbing lower branches of large trees, thinning smaller trees and brush, and small prescribed burns. An $\$ 80,000$ grant was secured from U.S. Fish and Wildlife Service (USFWS) to help carry out fuel reduction work in the reserve. In the late spring of 2006, crews from CAL FIRE removed brush and trees to create fuel breaks. However, not all portions of the VMP were implemented due to cost, time running out on the USFWS grant, lack of personnel, or objections by involved agencies. Today, there is still no overall Management Plan for the reserve (Beames 2008; CALFIRE 2004; Highlander 2006a, 2006b, 2006c). 


\section{Whitehurst Fire}

In southwestern Santa Clara County, the Whitehurst Fire burned within the Mount Madonna County Park from June 21-26, 2008. The lightning caused fire burned 103.6 hectares of redwood and mixed redwood forest between Highway 152 and Valley View Road (Figure 2). The area consists of stands of second growth redwood and mixed redwood forest. The large area of redwood allowed for sampling throughout a sizeable portion of the fire area. While there are many soil types within the Mt. Madonna County Park, the soil in the sampling area is Felton silt loam, which comes from weathered sandstone and shale (Natural Resources Conservation Service 2009).

What is now the Mt. Madonna County Park was part of the Las Animas Rancho during the Mexican land grant era. Small-scale logging began with early settlers, and later continued with more intensity by the poet Hiram Wentworth and the Whitehurst family. Redwood trees were the most coveted. Wentworth made shingles, fence posts, and housing materials, which were sold in Watsonville. The Whitehurst family used Bodfish Creek to transport their logs to Gilroy. After the 1906 earthquake, the largest scale old growth logging on the property occurred. The timber was used to help rebuild San Francisco. Tanoak was also desirable timber; it was widely used in local tanneries (personal communication, Senior Park Ranger John Heenan 2010).

Little is known about the fire history within Mt. Madonna County Park and the surrounding area. Loggers burned slash during clear-cut operations, as evidenced by scorched old growth stumps. There are no major fires in CAL FIRE records, which go back to the late 1940s (personal communication Battalion Chief Dave McLean 2010). 


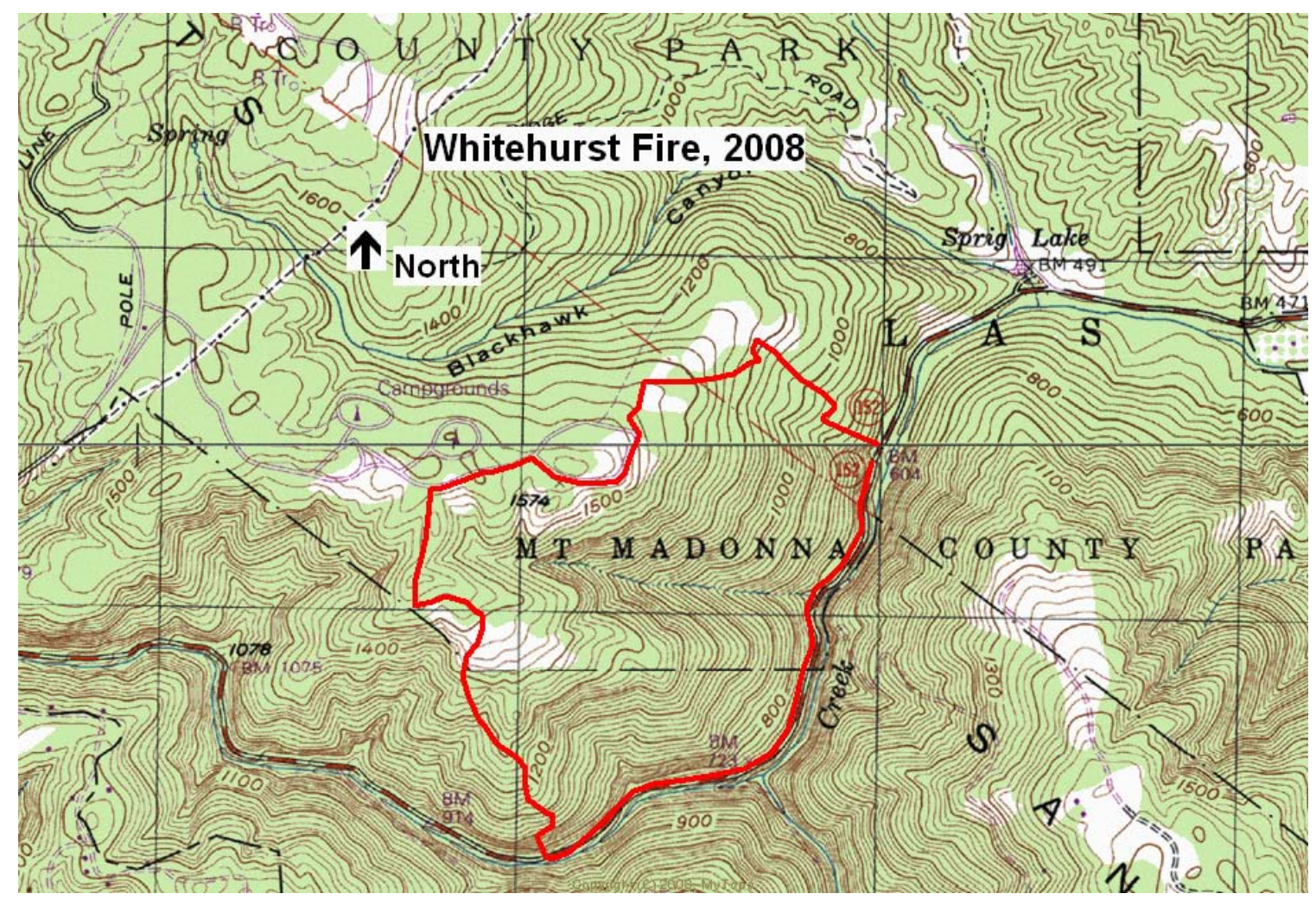

Figure 2. Whitehurst Fire perimeter map.

In 1859, cattleman Henry Miller purchased part of the Las Animas Rancho for cattle grazing. He purchased more land in 1875, eventually owning 5,665 hectares of the original rancho. Initially the Miller family used the mountain property as a rustic weekend retreat. The original cabin and wood floored tents were replaced with a main house and two large bungalows built between 1890 and 1902. Surrounding the main house was several acres of orchards and vineyards (personal communication Senior Park Ranger John Heenan 2010).

After Henry Miller's death, the state of California purchased a portion of the Miller property in 1927 . The original intention was for this land to become a state park. The Civilian Conservation Corps installed campsites in the 1930s. In 1953, Santa Clara 
County purchased the remainder of the Miller property and opened Santa Clara County's first county park (personal communication, Senior Park Ranger John Heenan 2010). The mission of the Santa Clara County Parks and Recreation Department is to "provide, protect and preserve regional parklands for the enjoyment, education and inspiration of this and future generations" (Santa Clara County Parks and Recreation Department 2003). Additional management goals are to understand, maintain, restore, preserve, and protect the integrity of the natural resources within the park (personal communication, Senior Park Ranger John Heenan 2010).

During the Whitehurst Fire, the main fire was mostly a ground fire. However, a back burn, an intentionally set fire to control fuels in the path of a wildfire, done along the western flank by CAL FIRE personnel burned at a higher intensity. There was little wind, so the fire did not travel along the ground. Instead, the heat from the fire went up into the canopy. In addition to the back burn, minimal fire suppression included some tractor lines and some hand lines. No structures were threatened and the fire occurred almost entirely on lands owned by Santa Clara County Parks, so there was no after action report by CAL FIRE (personal communication Battalion Chief Dave McLean 2010).

\section{Lockheed Fire}

From August 12-23, 2009, the Lockheed Fire burned 3,163 hectares in the Swanton area of coastal Santa Cruz County (Figure 3), in an area that had not seen fire since the 1948 Pine Mountain Fire. In addition to several smaller parcels of land, the major landholders that were affected by the fire included Lockheed Properties, Inc., Lone 
Star Cement Corporation, Big Creek Lumber and Timber Company, Swanton Pacific Ranch (Cal Poly), and the McCrary family. Sampling for this research took place on Swanton Pacific Ranch (SPR), which is a research facility for Cal Poly.

For several thousand years the Ohlone occupied this area, where they often set intentional fires. Fire was used to keep the valley area open for hunting, and to promote the growth of desirable native plant species (Anderson 2005). Native American burning most likely occurred for several thousand years on what are now SPR lands. Later, European settlers continued to burn to keep areas open for cattle. Fires may have spread from the grasslands into the forested areas (Forest plan Swanton Ranch 1991; Nonindustrial timber management plan 2007).

In 1843, under the Mexican land grant system, the area became known as Rancho Agua Puerca y Las Trancas, stretching from Davenport Landing to Las Trancas Creek just south of Waddell Creek. SPR now comprises much of Santa Cruz County's most northern rancho. Between 1843 and the early-1990's the land was farmed, ranched, logged, and homesteaded by many different owners. From 1907 to 1923 the forests were clear-cut by the San Vincente Lumber Company. The operations on present day SPR lands were most likely completed around 1910, and nearby lands were logged until 1923. The timber was used as building materials by early Swanton settlers, and to rebuild San Francisco after the 1906 earthquake. Tanoak bark was harvested during this time for use in local tanneries. The land also supported cattle, dairy, and agriculture operations, as well a cheese factory (Forest plan Swanton Ranch 1991; Swanton draft management plan 2004). 


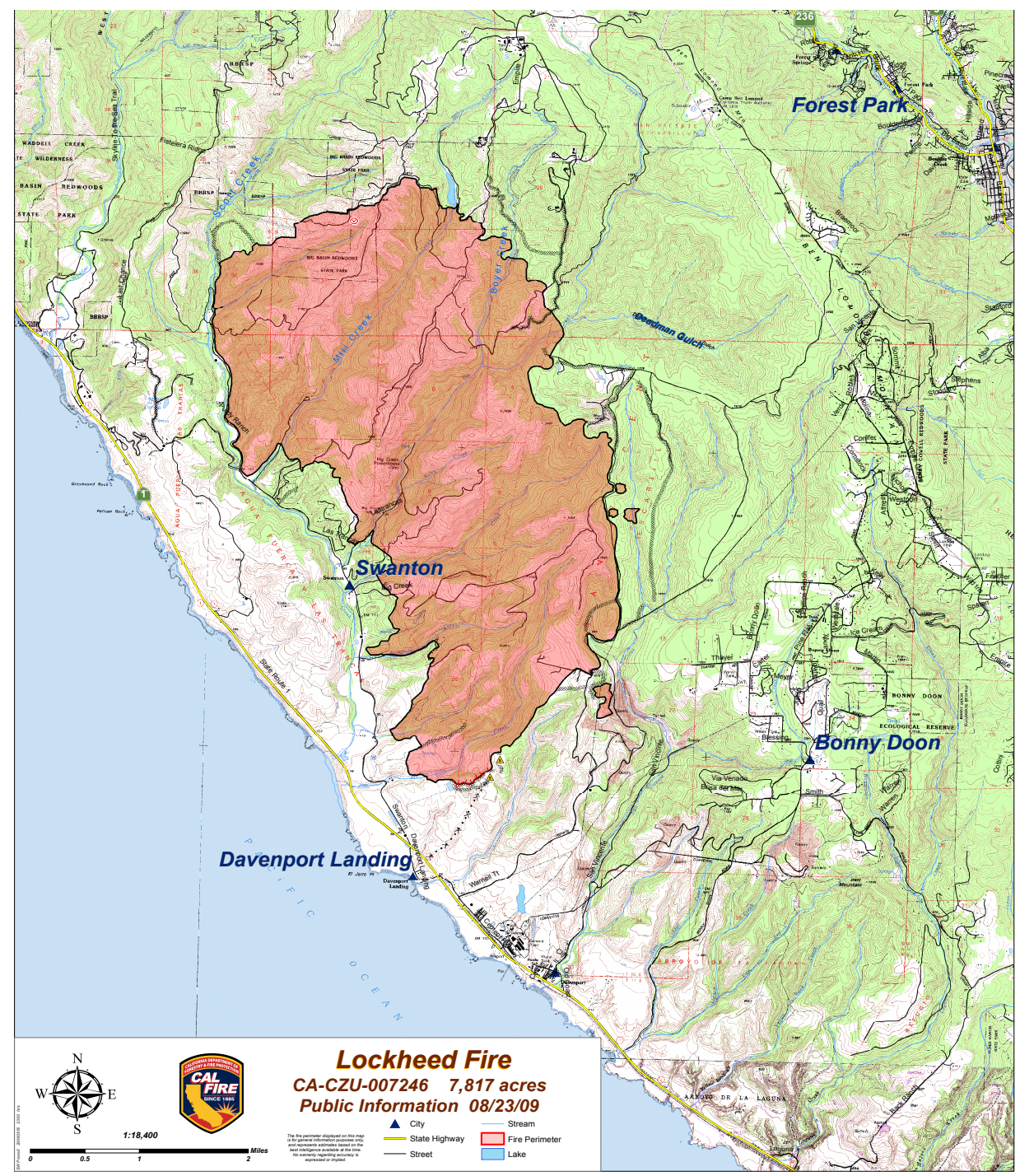

Figure 3. CAL FIRE map of the Lockheed Fire. The study area was east slightly northeast of Swanton, which is indicated on the map. Map courtesy of CAL FIRE.

There was extensive slash burning after early timber harvests. Burning the slash mage retrieving fallen trees easier. In 1923, one of the slash fires flared up and caused a larger than normal fire. The largest fire in recent times was the Pine Mountain Fire in 1948. The fire burned over the course of four or five weeks. It reached the upper portions of Little Creek in the last week. The intense fire left many trees scarred, and 
these scars can be seen on some redwood and Douglas fir trees today (Nonindustrial timber management plan 2007).

In 1993, Al Smith donated the ranch to Cal Poly. Since that time, Cal Poly students, as well as students and researchers from other institutions, have researched sustainable forestry, sustainable agriculture, watershed management, and rangeland management on the ranch's 1,295 hectares (Swanton draft management plan 2004).

Of SPR's 1,295 hectares, roughly 580 are forested. The main forest-land is located in the Little Creek Management Unit on the eastern side of the property along Little Creek and several intermittent creeks, which all drain to Scotts Creek. Data collection for this study took place in the Little Creek Management Unit, which consists of 348 hectares, with 128 acres considered harvestable (Forest plan Swanton Ranch 1991; Swanton draft management plan 2004; Nonindustrial timber management plan 2007). Soils in this area include Ben Lomond-Catelli-Sur complex, Santa Lucia shaly clay loam, and Bonnydoon loam. Ben Lomond-Catelli-Sur complex consists of material from weathered granite, sandstone, and/or schist. Santa Lucia shaly clay loam is mainly derived from weathered shale. Bonnydoon loam's parent material comes from weathered from mudstone, sandstone, and/or shale (Natural Resources Conservation Service 2009).

Between 1907 and 1910 the old growth redwoods were clear cut and burnt. In the 1960's, about 16 hectares of second growth forest was cut. Today the management unit contains of mostly even aged coast redwood and Douglas fire, except in the area harvested in the 1960's, with an understory of tanoak. SPR management practices are attempting to convert the forest to uneven aged stands through selective harvests. Timber 
harvests in 1989-1990, 1990-199, 1993-1995, and 2004 in various parts of the management unit used individual and group selective cuts, ground skidding, and swing and skyline yarding. In May 2004, the Forest Stewardship Council (FSC) awarded SPR the "well managed forest" certification. A Nonindustrial Timber Management Plan (NTMP) was written for Swanton Pacific Ranch in 2007-2008. The NTMP serves as a long-term management plan for future timber harvest on SPR. In 2008 the North Fork of the Little Creek Unit was harvested under the NTMP (Forest plan Swanton Ranch 1991; Swanton draft management plan 2004; Nonindustrial timber management plan 2007).

After the Lockheed Fire, salvage logging was conducted in some areas of the Little Creek Management Unit. Foresters from SPR and Big Creek lumber determined which trees were considered dangerous or unlikely to survive due to fire damage, and these trees were removed. Individual trees were mainly removed via helicopter to reduce damage to surviving trees and to prevent erosion (personal communication SPR Natural Resources Manager Steve Auten 2010). 


\section{Plot Design}

Sampling areas for each fire were predetermined using fire maps obtained from CAL FIRE. Areas with salvage harvesting, not containing redwood or mixed redwood communities, or not burnt were excluded from sampling. Starting points for selecting plots were randomly chosen before data collection. Once in the field subsequent plot locations were randomly selected.

Sampling was conducted using 90 randomly located circular plots with a diameter of 10 meters (78.5 square meters). In areas of low tree density, this plot size was large enough to capture tree data, but was not too large to be unmanageable to measure (Brower, Zar, and von Ende 1998; Reid and Thompson 1996). Trees that were located at least halfway within the plot boundary were counted. Trees that fell less than halfway inside the plot, or completely outside of the plot, were not counted (Figure 4).

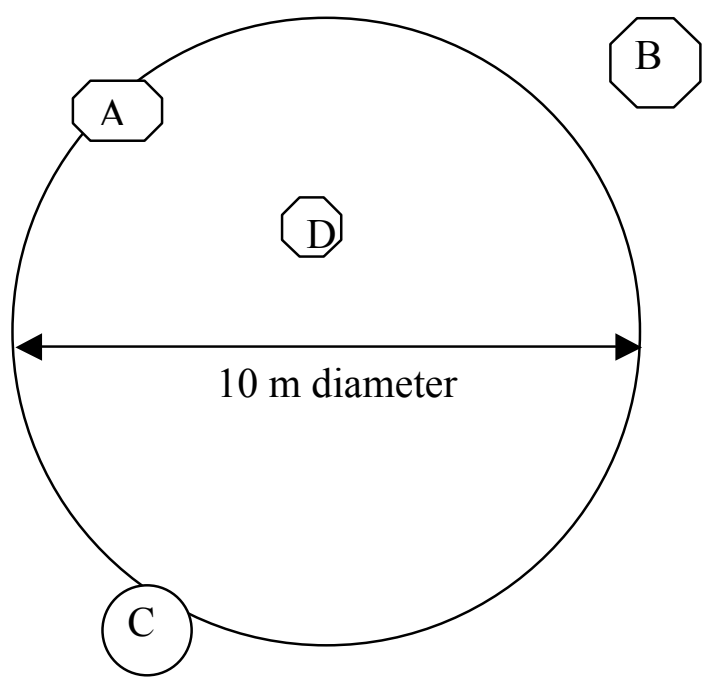

Figure 4. Diagram of plot design. Trees labeled A and D were considered inside the plot. Trees $\mathrm{B}$ and $\mathrm{C}$ were considered outside the plot. 


\section{Measurements}

Data collection took place from January 2009 to September 2010. This lapse in time between the fires and data collection allowed greater accuracy in tree mortality caused by the fire (Kobziar, Moghaddas, and Stephens 2006).

Environmental data, slope, aspect, and depth of duff, was measured from the center of each plot. Additionally, canopy cover was measured at the center of each plot using a spherical densiometer. This instrument provides a compromise between the sight tube method, which is precise but time consuming, and visually estimating canopy cover, which is typically the least accurate method of measurement, but can be done quickly (Korhonen et al. 2006). Three types of canopy cover were measured in each plot: total canopy cover, the percent of residual foliage, and the percent regenerated foliage. Residual foliage was defined as living foliage that did not burn in the fire, and regenerated foliage was defined as new foliage that had grown after the fire.

Parameters measured for all trees within a sampling plot included diameter at breast height $(\mathrm{DBH})$, tree height, and the height of scorch on tree trunks (which was used as a proxy for flame length), as well as identification of species. In plots 9 to 20 at the Martin Fire site, individual tree height and individual scorch heights were not measured. For these plots, the tallest tree and highest scorch were recorded. Tests comparing tree height and scorch height were done without the data from these plots. DBH was measured at $1.4 \mathrm{~m}$ above the ground on the upslope side of each tree. A clinometer was used to take the various height measurements. Two types of tree survival were recorded for each tree: crown survival and overall survival. Overall survive was defined as any 
tree with residual crown, regenerated crown, or basal sprouts. Crown survival was defined as trees with residual and/or regenerated crown. Three types of regeneration were measured: 1. Epicormic regeneration was based on post-fire canopy sprouting; 2. Basal regeneration was based on the number of sprouts in three size classes (Busing and Fujimori 2002) and size classes of sprouts were based on the height of sprouts $(1 .<0.5 \mathrm{~m}$ tall; 2. $0.5-1.0 \mathrm{~m}$ tall; $3 .>1.0 \mathrm{~m}$ tall); and 3. Total number of seedlings counted within each plot.

All trees were identified to species except for oaks (Quercus) and willows (Salix). In the Santa Cruz Mountains three species of oak are commonly found: coast live oak $(Q$. agrifolia), canyon live oak (Q. chrysolepis), and interior live oak (Q. wislizenii). A fourth species, Shreve oak (Q. parvula var. shrevei), can be found in the Bonny Doon area of the Santa Cruz Mountains. Oaks frequently hybridize, making identification difficult (Pavlik et al. 2006). Additionally, young sprouts and shoots look very similar. For these reasons, all Quercus species were counted together. Similarly, the two willows species, arroyo willow (Salix lasiolepis) and Scouler's willow (Salix scoulariana), found in the Bonny Doon Ecological Reserve (the only site with willows present in the study plots) can be difficult to tell apart, and were not distinguished.

\section{Analysis}

Ecological data on the five most common species were examined statistically. Species with few occurrences were considered minor components, and were not included in analysis for this study. For all statistical tests, alpha equaled 0.05, and all tests were 
performed using Systat 13. Graphs were produced using Excel 2008.

Three sets of descriptive statistics were calculated for each site: 1) the total number of trees of each species, 2) the percent species composition of each tree species, and 3) the percent of tree scorched was calculated from the tree height and scorch height data (for the plots from which this data were available). ANOVA was used to test for any significant differences in mean percent scorch between species, and t-Tests were used post-hoc to determine which species' mean percent scorch were significantly different from each other. The percent scorch data supplements the same tests done with scorch height data. In some cases, such as a large range in tree heights, the percent scorch data is more useful than the scorch height data. Hypothesis specific analysis procedures are described below.

\section{Hypothesis 1) Redwood trees are more resistant to fire than associated tree species.}

a. Redwood trees are less likely than associated tree species to have overall mortality caused by fire.

To assess whether coast redwood trees experienced less mortality than associated tree species, ANOVAs were performed to test for significant differences between species of mean overall survival of trees in each plot. Two sample t-tests were used as a post-hoc test to determine which species had significantly different levels of survival. This was also done separately for each of the three sites. Simple Correlations were performed using plot level data to determine if there was a relationship between overall survival and highest scorch of plot, tallest tree of plot, mean $\mathrm{DBH}$, aspect, or slope. 
b. Redwood trees are less likely than associated tree species to have crown mortality caused by fire.

To assess whether redwood trees had less crown mortality than associated tree species, ANOVAs were performed to test for significant differences between species of mean crown survival. Two sample t-tests were used as a post-hoc test to determine which species had significantly different levels of crown survival. This was also done for each of the three sites. Simple Correlations tests were performed using plot level data to determine if there was a relationship between crown survival and highest scorch of plot, tallest tree of plot, mean DBH, aspect, or slope.

The mean percent crown survival was compared using t-tests between plots with and without redwood trees present to assess how the fires behaved in plots of different forest types. This was done for the three sites combined and separately.

c. Redwood trees are more likely to have residual canopy after fire than associated tree species.

The total percent of trees with residual canopy was calculated for the five most common species. Using tree level data, trees with residual canopy were contrasted with trees without residual canopy using two sample t-tests to determine if there was a significant difference in percent of tree scorched, tree height, $\mathrm{DBH}$, aspect, or slope for each of the five most common species. Additionally, using plot level data Simple Correlations were used to assess the relationship between percent residual canopy cover and highest tree of plot, $\mathrm{DBH}$, aspect, or slope. 
Hypothesis 2) Redwood trees have different levels of resiliency after fire than associated tree species.

a. Redwood trees are more likely to have regenerated canopy after fire than associated tree species.

The total percent of trees with regenerated canopy was calculated for the five most common species. Using tree level data, trees with regenerated canopy were contrasted with trees without regenerated canopy using two sample t-tests to determine if there was a significant difference in percent of tree scorched, tree height, DBH, aspect, or slope for each of the five most common species. Additionally, using plot level data Simple Correlations were used to assess the relationship between percent regenerated canopy cover and highest tree of plot, DBH, aspect, or slope.

b. Redwood trees have greater basal regeneration after fire than associated tree species.

Douglas fir was not included in the analysis of basal sprouts because it does not have the ability to sprout. The total number of basal sprouts, total number of basal sprouts per plot, and total number of basal sprouts per plot by site were calculated. For each plot, the mean number of basal sprouts of each of the four most common species was calculated. An ANOVA was then conducted to determine if there was a significant difference in the mean number of basal sprouts per plot between the four species. Two sample t-tests were used as a post-hoc test to determine which species had significantly different mean numbers of basal sprouts per plot. For each of the four species, the mean number of basal sprouts per tree was calculated. An ANOVA was performed to test for 
significant differences in the mean umber of basal sprouts per tree. Two sample t-tests were then used as a post-hoc test to determine which species had significantly different mean numbers of basal sprouts per tree. Using plot level data, Simple Correlations were used to assess the relationship between the number of basal sprouts per plot of each of the four most common species and highest scorch of plot, tallest tree of plot, mean DBH, aspect, or slope. Using individual tree data, Simple Correlations were used to assess the relationship between number of basal sprouts per tree for each of the four most common species and scorch height, percent scorch, tree height, and DBH. If a significant correlation was found, linear regression analysis was then conducted.

c. Redwood seedlings are less likely to germinate after fire than the seedlings associated tree species.

The total number of seedlings of each of the five most common species was calculated for each of the three sites. Due to the high number of seedlings on the Whitehurst site, the data was log transformed in order to better represent all five species. Simple Correlations were performed to test for a relationship between number of seedlings and canopy cover, duff depth, aspect, and slope.

\section{Limitations}

The nature of studies on the effects of wildfires is that they must take advantage of unplanned events. While pre-fire conditions can be approximated, exact conditions are rarely fully understood. Fortunately, nearly all trees retained some needle, leaf, and/or 
bark material by which to determine species and whether mortality was due to the fire. However, several trees were burned to the point that pre-fire condition was indeterminable. Because these trees were included in analyses of mortality, one limitation of this study is that calculated mortality may be slightly higher than the actual fire caused mortality.

A second limitation resulted from post-fire salvage logging that occurred at the Lockheed Fire site. Because salvage logged areas were excluded from this study, the total sample area was reduced. In spite of this restriction, the area that was available for sampling proved sufficient. 


\section{RESULTS}

This section begins with an analysis of the tree species sampled, the species composition of each site, and scorch characteristics of the five most common species. Data is then presented on survivorship and regeneration after fire of redwood and four associated species.

Altogether, 637 trees were measured: 277 at the Martin site, 197 at the Whitehurst site, and 163 at the Lockheed site. In total, 13 species were sampled (Table 2). Four species were found at all three of the study sites: coast redwood (S. sempervirens), tanoak (L. densiflorus), oak (Quercus spp), and madrone (A. menziesii). Douglas fir ( $P$. menziesii) was only found at two of the three sites, and it was an important species at these sites. These five species were used for statistical analysis.

Overall, $51.3 \%$ of trees were redwood. Redwood was the most frequently sampled species at each site: $38.6 \%, 71.6 \%$, and $48.5 \%$, respectively, at Martin, Whitehurst, and Lockheed were redwood. Tanoak was the second most common species at each site. However, the species composition of each site varied greatly (Figure 5). 
Table 2. Number of trees sampled on three sites in the Santa Cruz Mountains by site.

\begin{tabular}{|l|l|l|l|l|l|}
\hline Common Name & Scientific Name & Martin & Whitehurst & Lockheed & Total \\
\hline Pacific madrone & Arbutus menziesii & 18 & 11 & 5 & 34 \\
\hline Manzanita & Arctostaphylos spp & 4 & 0 & 0 & 4 \\
\hline $\begin{array}{l}\text { Coast } \\
\text { chinquapin }\end{array}$ & $\begin{array}{l}\text { Chrysolepis } \\
\text { chrysophylla }\end{array}$ & 4 & 2 & 0 & 6 \\
\hline Tanoak & Lithocarpus densiflorus & 58 & 32 & 44 & 134 \\
\hline $\begin{array}{l}\text { California Wax- } \\
\text { myrtle }\end{array}$ & Myrica californica & 1 & 0 & 0 & 1 \\
\hline Knobcone pine & Pinus attenuata & 2 & 0 & 0 & 2 \\
\hline Ponderosa pine & Pinus ponderosa & 4 & 0 & 0 & 4 \\
\hline Douglas fir & Pseudotsuga menziesii & 22 & 0 & 19 & 41 \\
\hline Oaks & Quercus spp & 54 & 9 & 13 & 76 \\
\hline Willows & Salix spp & 3 & 0 & 0 & 3 \\
\hline Coast redwood & Sequoia sempervirens & 107 & 141 & 79 & 372 \\
\hline $\begin{array}{l}\text { California } \\
\text { Nutmeg }\end{array}$ & Torreya californica & 0 & 0 & 3 & 3 \\
\hline California Bay & Umbellularia californica & 0 & 2 & 0 & 2 \\
\hline Total & & 277 & 197 & 163 & 637 \\
\hline
\end{tabular}

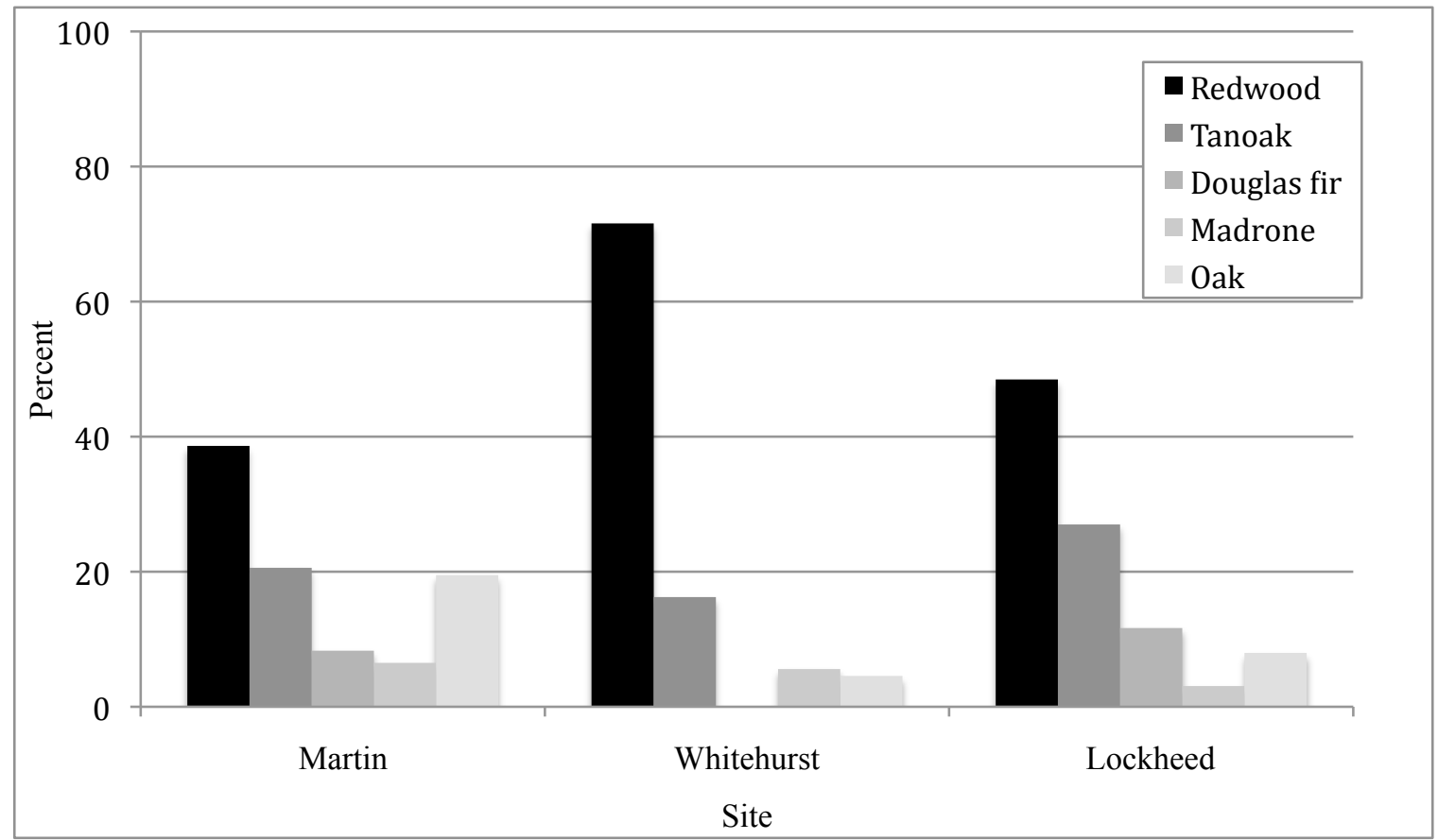

Figure 5. Post-fire percent composition of the five most common trees species on three sites in the Santa Cruz Mountains. 
Combining the three sites, madrone had the highest mean percent of tree scorched $(69.1 \%+-9.0 \mathrm{SE})$, and had significantly higher percent scorch than redwood, tanoak, Douglas fir, and oak (F-ratio $=14.507, \mathrm{df}=4, \mathrm{p}<0.001$, Figure 6). Redwood had the next highest mean percent scorch at $47.523 \%+-1.7$, and was significantly higher than tanoak, Douglas fir, and oak. Douglas fir at $35.9 \%+-4.89$, oak at $29.2 \%+-4.4$, and tanoak at $27.6 \%+-3.0$ were not significantly different from each other.

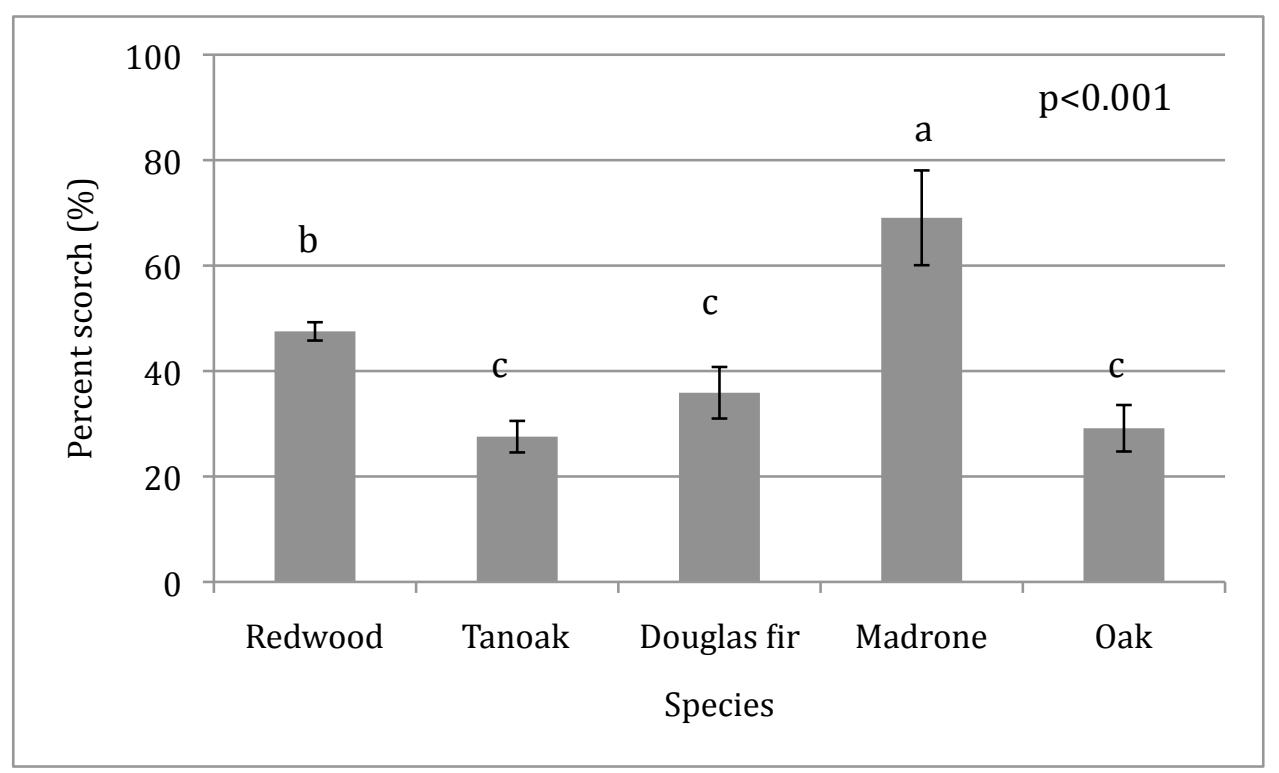

Figure 6. Percent of tree scorched for five most common tree species (mean $\%+$ - SE) on three sites in the Santa Cruz Mountains. Species with the same lower case letter are not significantly different from each other. 


\section{Resistance to Fire}

Overall survival

Regardless of site, redwood had the highest mean overall survival, and had significantly higher $(\mathrm{F}-\mathrm{ratio}=13.889, \mathrm{df}=4, \mathrm{p}<0.001)$ mean overall survival than Douglas fir and oak. Tanoak, madrone, and oak also had relatively high mean overall survival rates (Figure 7). When site was taken into consideration there was little variation between redwood, tanoak, madrone, and oak on the Martin and Whitehurst sites, and little variation between redwood, tanoak, Douglas fir, and oak on the Lockheed site (Figure 8). Highest scorch of plot and percent overall survival were not correlated. 


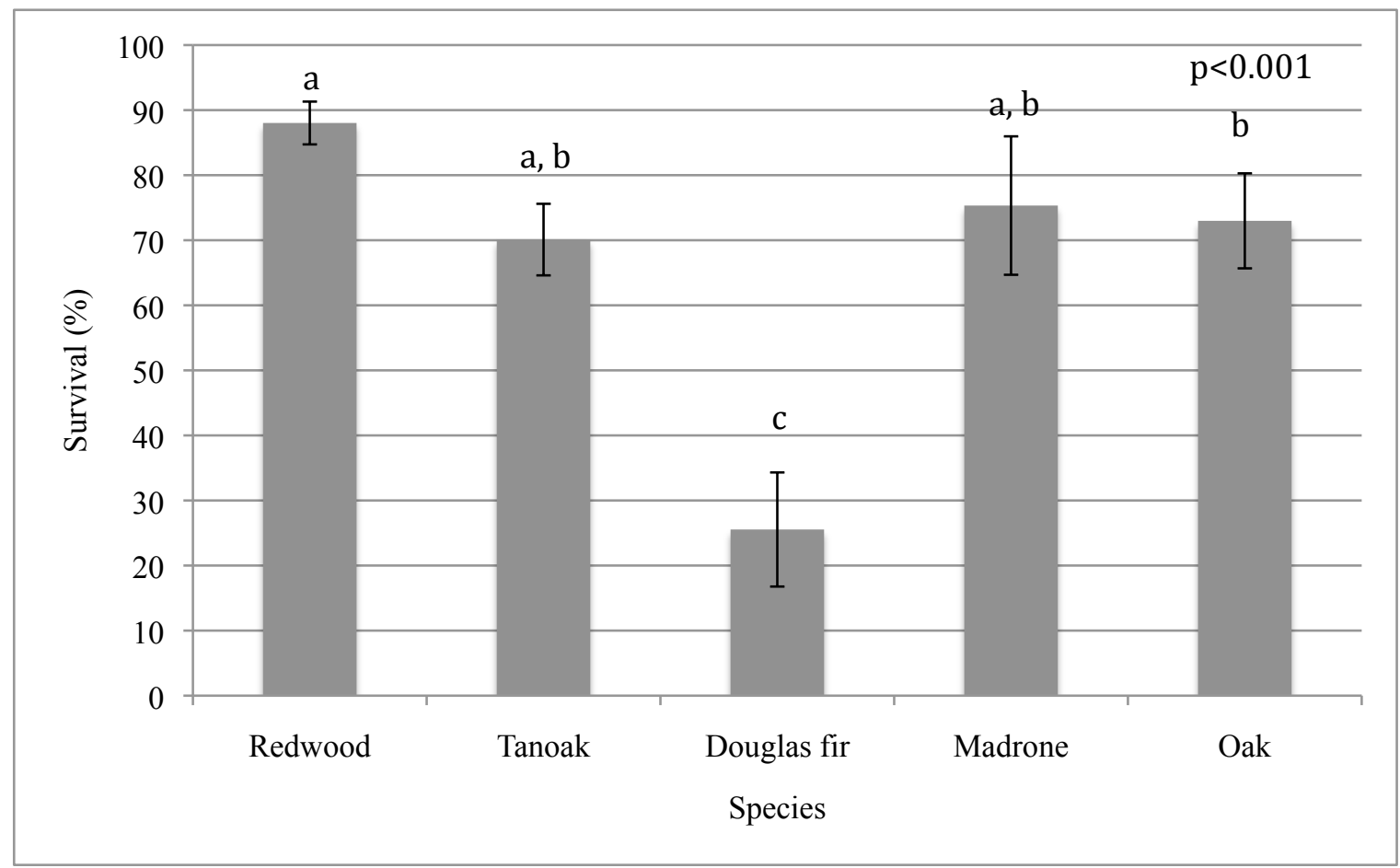

Figure 7. Post-fire overall survival (mean $\%+$ - SE) of five most common tree species for three sites in the Santa Cruz Mountains. Species with the same lower case letter are not significantly different from each other.

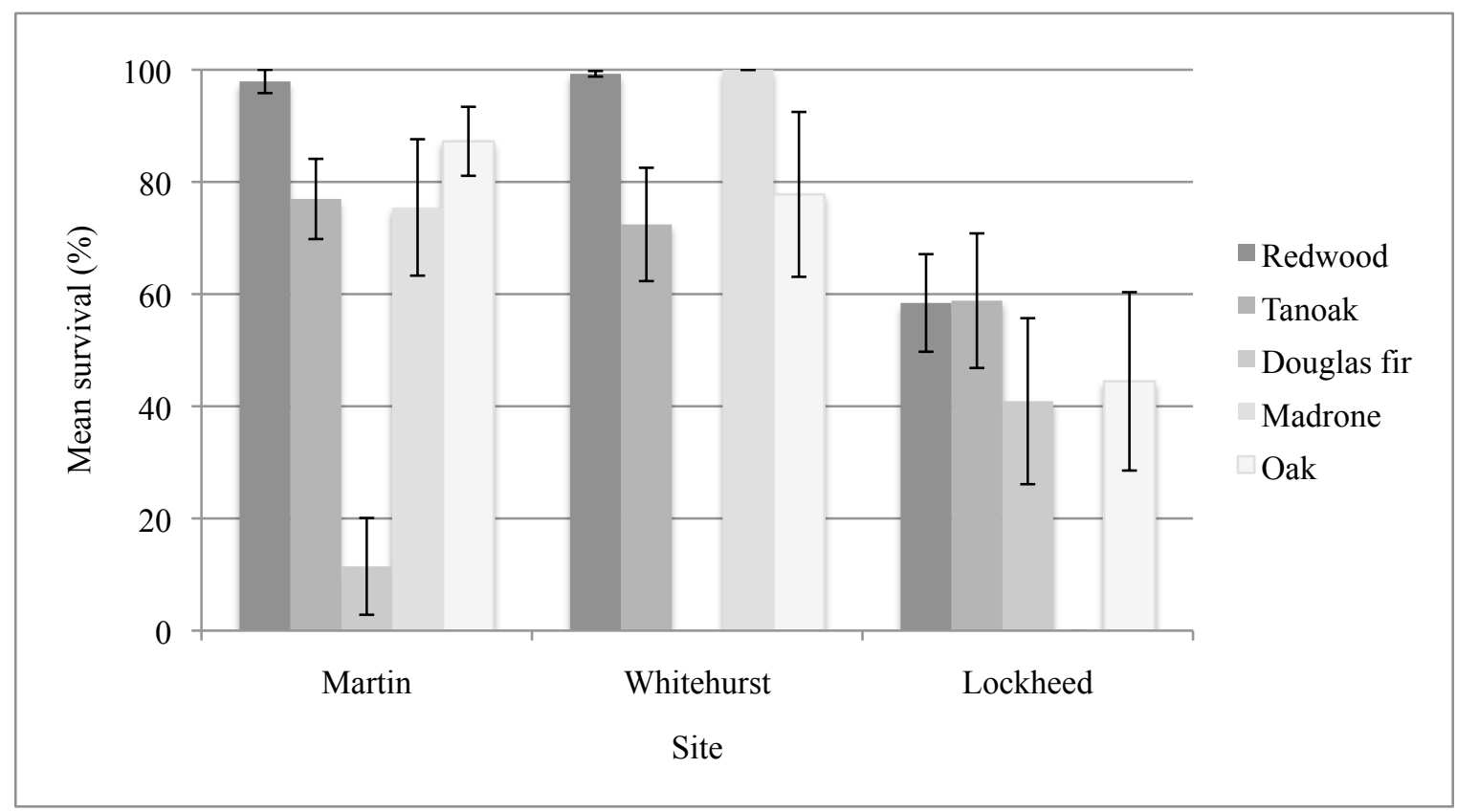

Figure 8. Post-fire overall survival (mean $\%+$ - SE) of five most common tree species on three sites in the Santa Cruz Mountains by site. 


\section{Crown survival}

When considering the data from the three sites together, redwood trees also had the highest mean crown survival, and had significantly higher (F-ratio $=7.234, \mathrm{df}=4$, $\mathrm{p}<0.001)$ mean crown survival than the other four most common species. Tanoak and Douglas fir had moderate mean crown survival, while madrone and oak had low mean crown survival (Figure 9). When site was taken into consideration, levels of mean crown survival varied among species, as well as among plots. The Martin site had the lowest redwood mean crown survival, while the Whitehurst site had the highest redwood mean crown survival. Tanoak and Douglas fir had the highest mean crown survival at the Lockheed site (Figure 10). Highest scorch of plot did not have a correlation with percent crown survival.

When plots from across the three sites with and without redwood tree present were compared, plots with redwood trees present had a higher mean percent crown survival than plots with no redwood trees present. Although the difference was not statistically significant $(\mathrm{t}=1.925, \mathrm{p}=0.057)$, there is a strong trend that plots with at least one redwood tree present had higher crown survival (Figure 11). When the three sites were analyzed separately, the Martin and Whitehurst sites had dramatically higher mean percent crown survival on plots with redwood trees present. The Lockheed site, however, had nearly identical mean crown survival between plots with and without redwood trees present (Figure 12). 


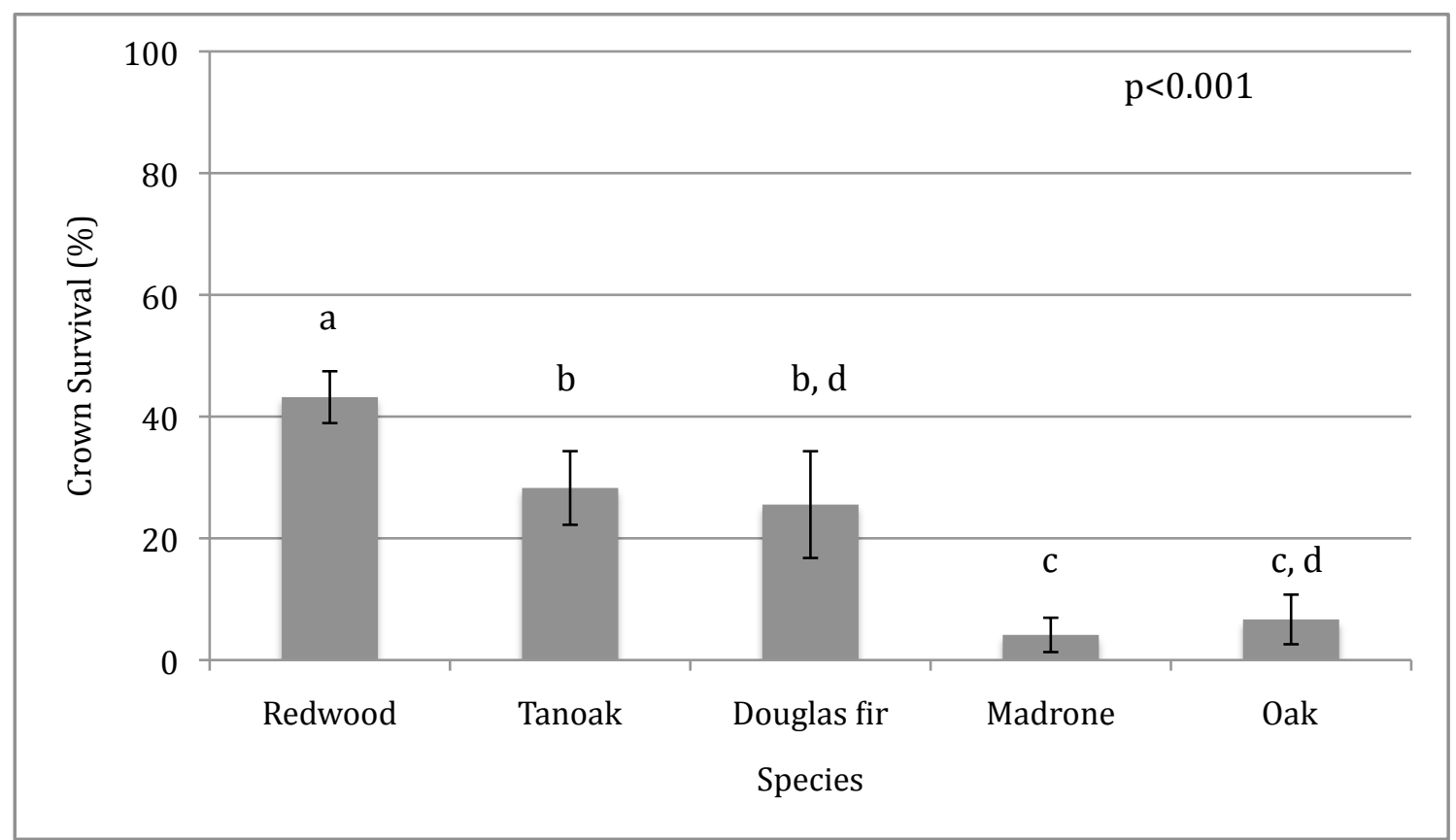

Figure 9. Post-fire crown survival (mean $\%+$ - SE) of five most common tree species on three sites in the Santa Cruz Mountains. Species with the same lower case letter are not significantly different from each other.

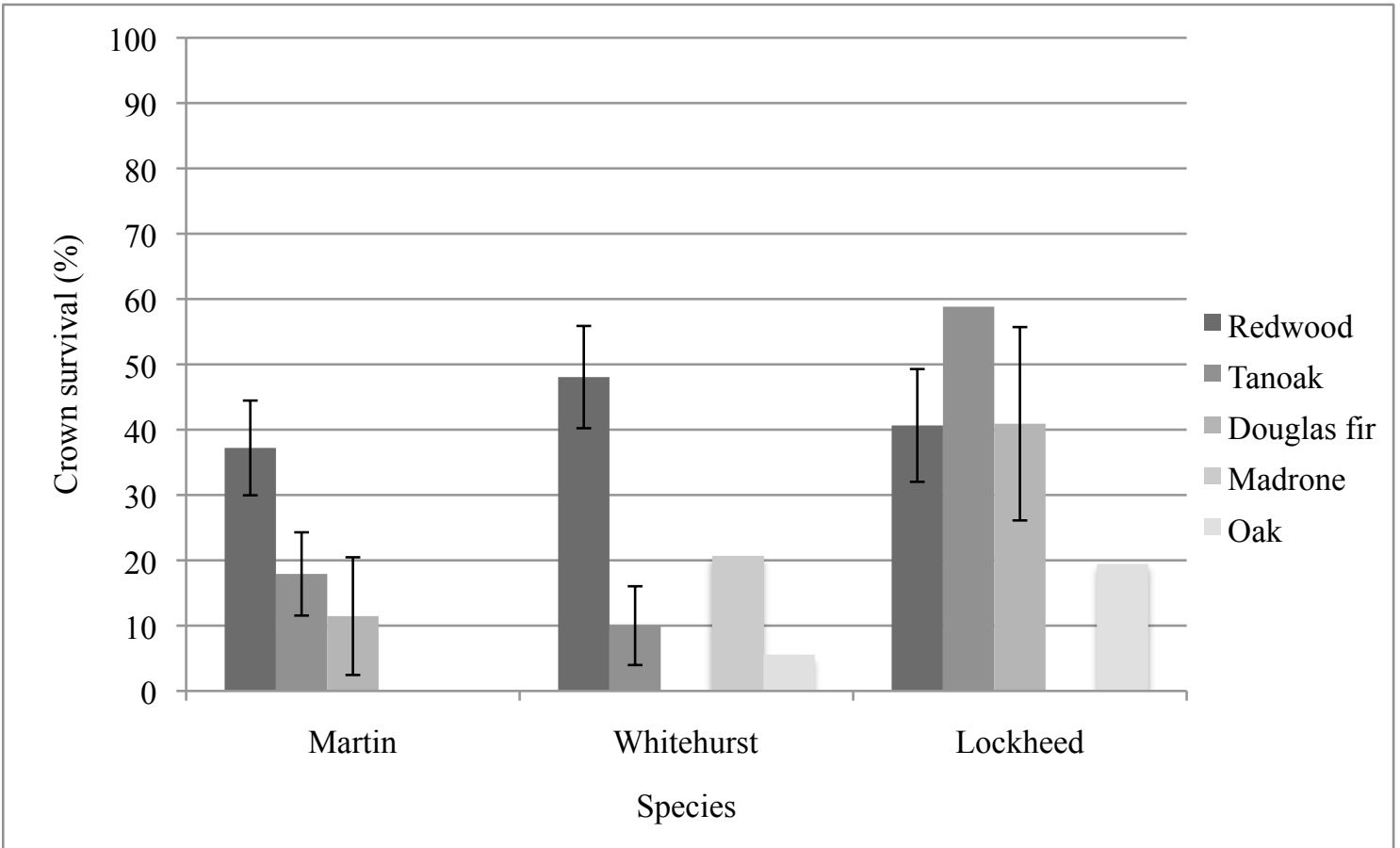

Figure 10. Post-fire crown survival (mean $\%+$ - SE) of five most common tree species on three sites in the Santa Cruz Mountains by site. 


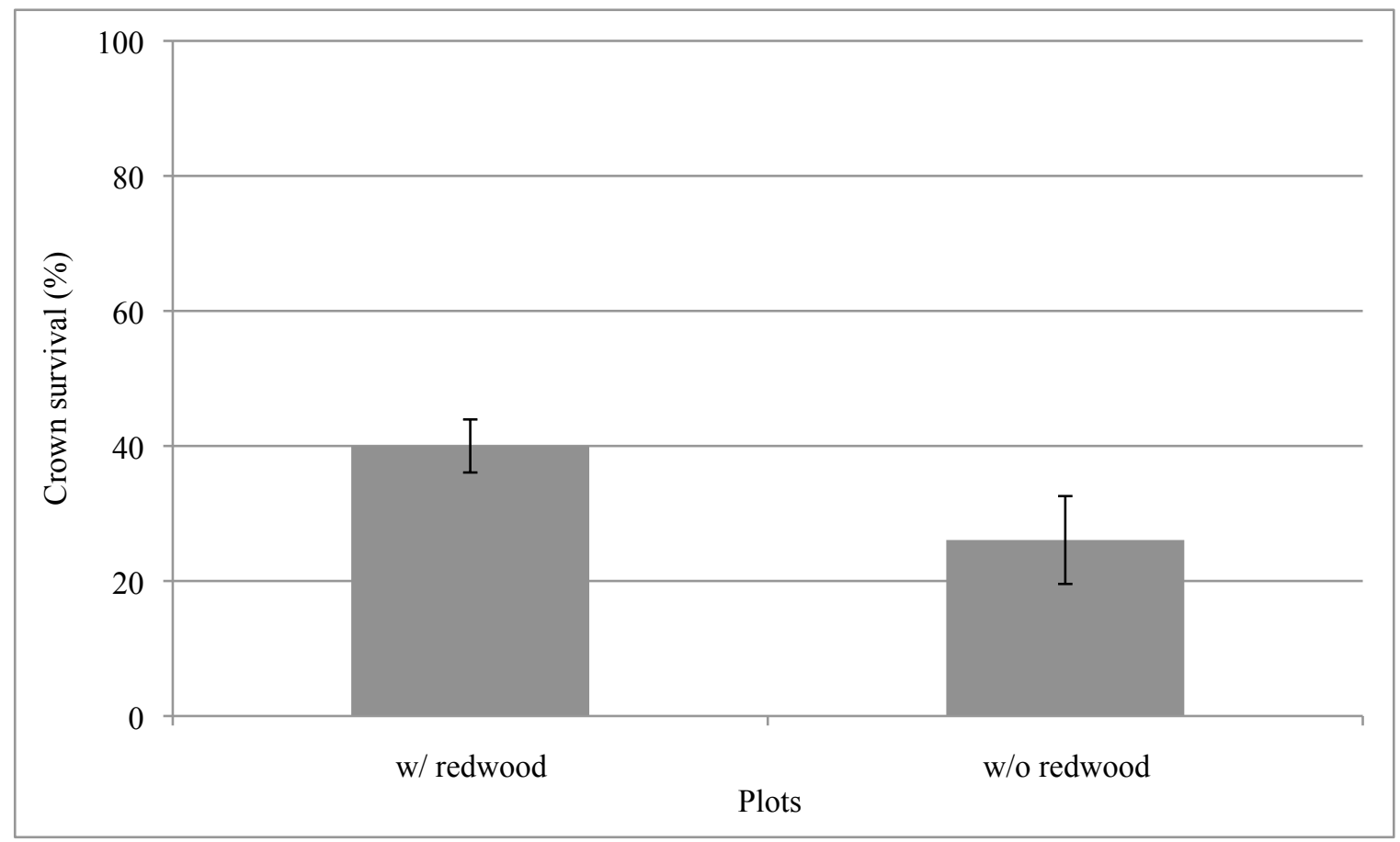

Figure 11. Crown survival on plots with and without redwood trees present (mean $+-\mathrm{SE})$ on three sites in the Santa Cruz Mountains.

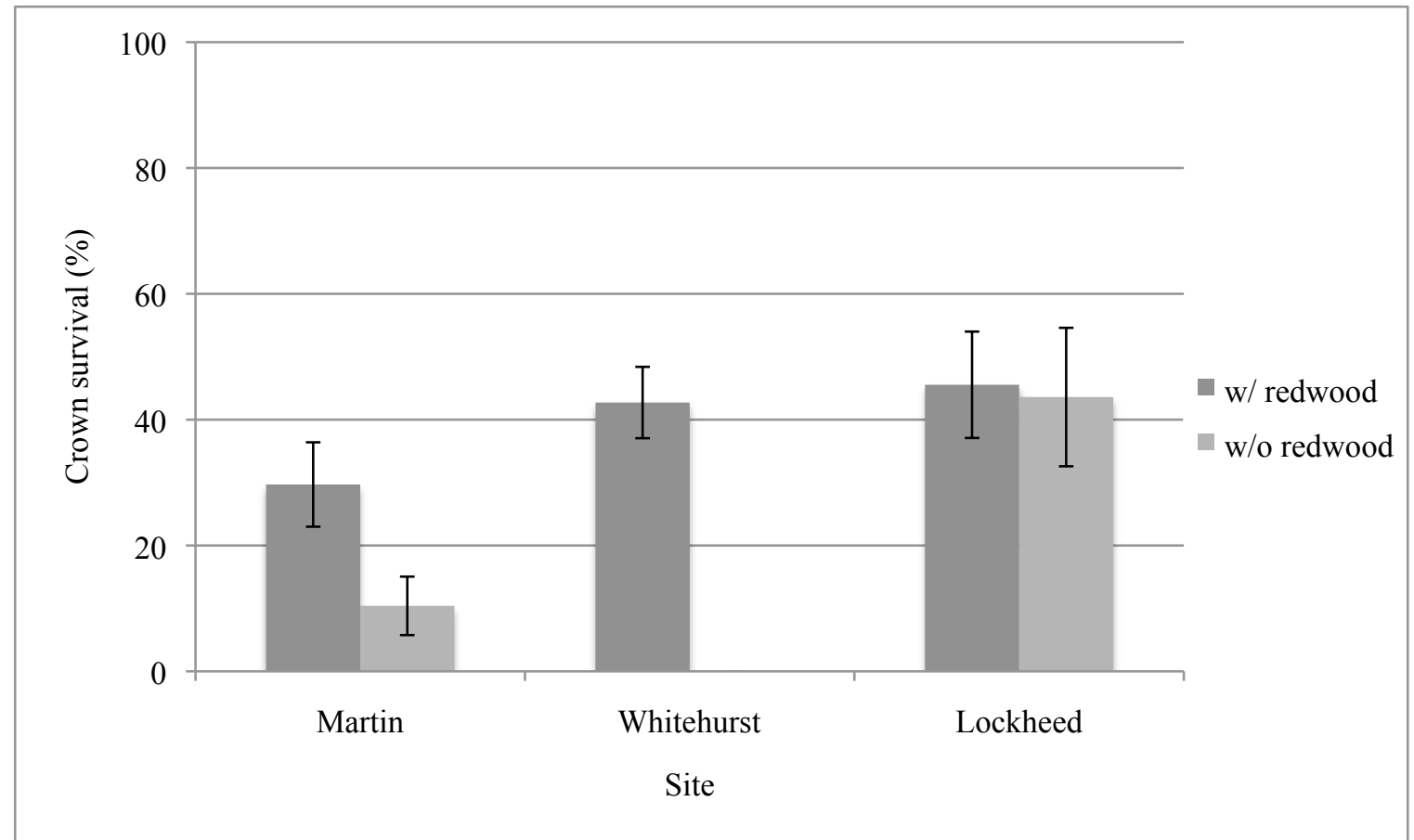

Figure 12. Crown survival on plots with and without redwood trees present (mean $+-\mathrm{SE}$ ) grouped by three sites in the Santa Cruz Mountains. 


\section{Residual canopy}

Redwood trees had the highest percentage of trees with residual canopy (Figure 13), despite having a higher mean percent scorch than most associates. When mean scorch height of trees with and without the presence of residual canopy was compared, redwood was the only species that had a significantly higher mean scorch height for trees with residual canopy. Conversely, madrone trees had a significantly higher mean scorch height for trees without residual canopy (Figure 14). In some cases, such as a large range in tree heights, the percent scorch data was more reflective of fire impact than the scorch height data. When mean percent of tree scorched was compared for trees with and without residual canopy, redwood, tanoak, madrone, and oak had significantly higher mean percent scorch for trees without residual canopy (Figure 15). Redwood, tanoak, madrone, and oak each had significantly higher mean tree heights for trees with residual canopy than for trees without residual canopy. The difference between the mean tree height for trees with and without residual canopy was the most dramatic for redwood trees (Table 3). Additionally, redwood, tanoak, and oak each had a significantly larger mean DBH for trees with residual canopy present than for trees without residual canopy present. The difference in mean DBH for redwood trees with and without residual canopy was again the most dramatic (Table 4). Oak trees with residual canopy had a significantly $(\mathrm{t}=3.012, \mathrm{df}=5.557, \mathrm{p}=0.026)$ higher mean aspect than trees without residual canopy: 237.5 degrees +-16.0 for trees with residual canopy and 181.2 degrees +-9.7 for tress without residual canopy. Tanoak trees with residual canopy had a significantly $(\mathrm{t}=2.517, \mathrm{df}=132.0, \mathrm{p}=0.013)$ steeper slope $(47.4 \%+-4.9)$ than trees without residual 
canopy $(33.2 \%+-2.9)$. There was no correlation between highest scorch of plot and percent total residual canopy.

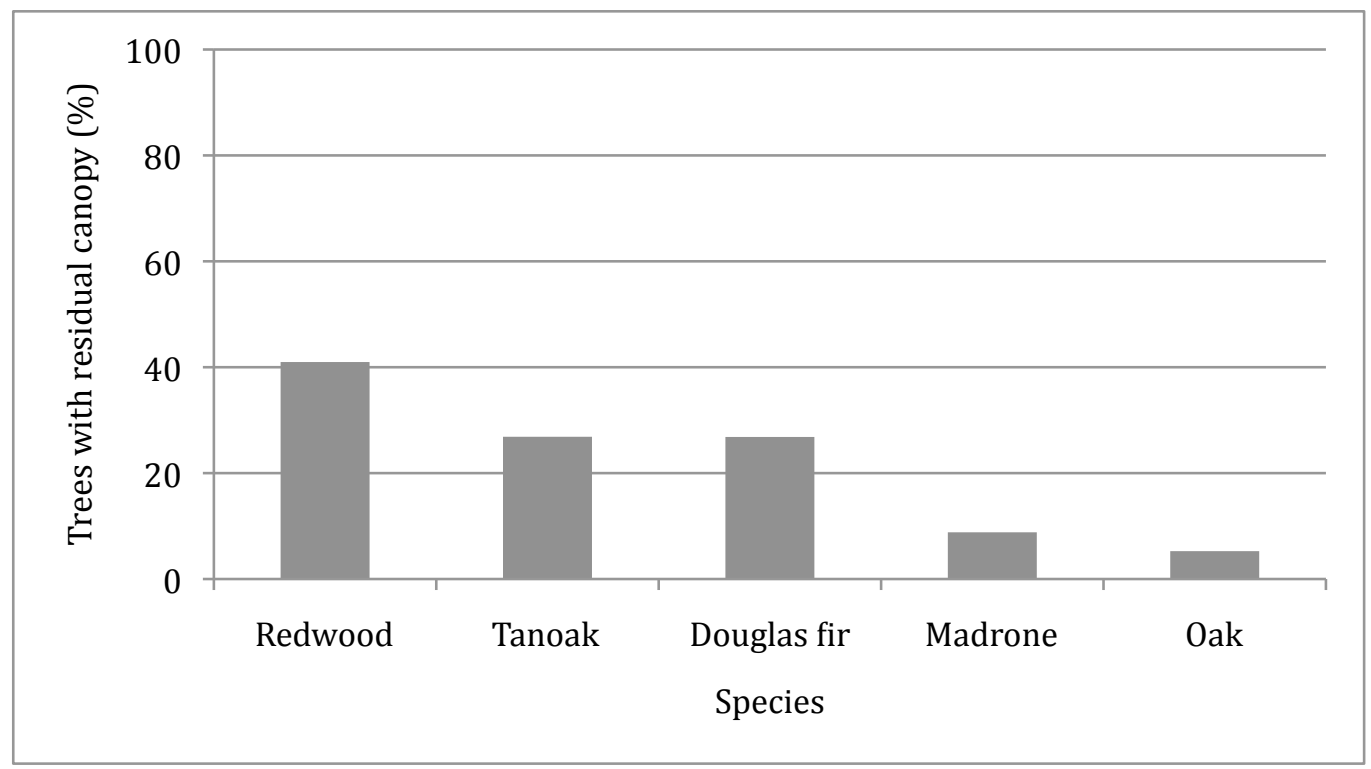

Figure 13. Percent of trees with post-fire residual canopy of five most common tree species on three sites in the Santa Cruz Mountains. 


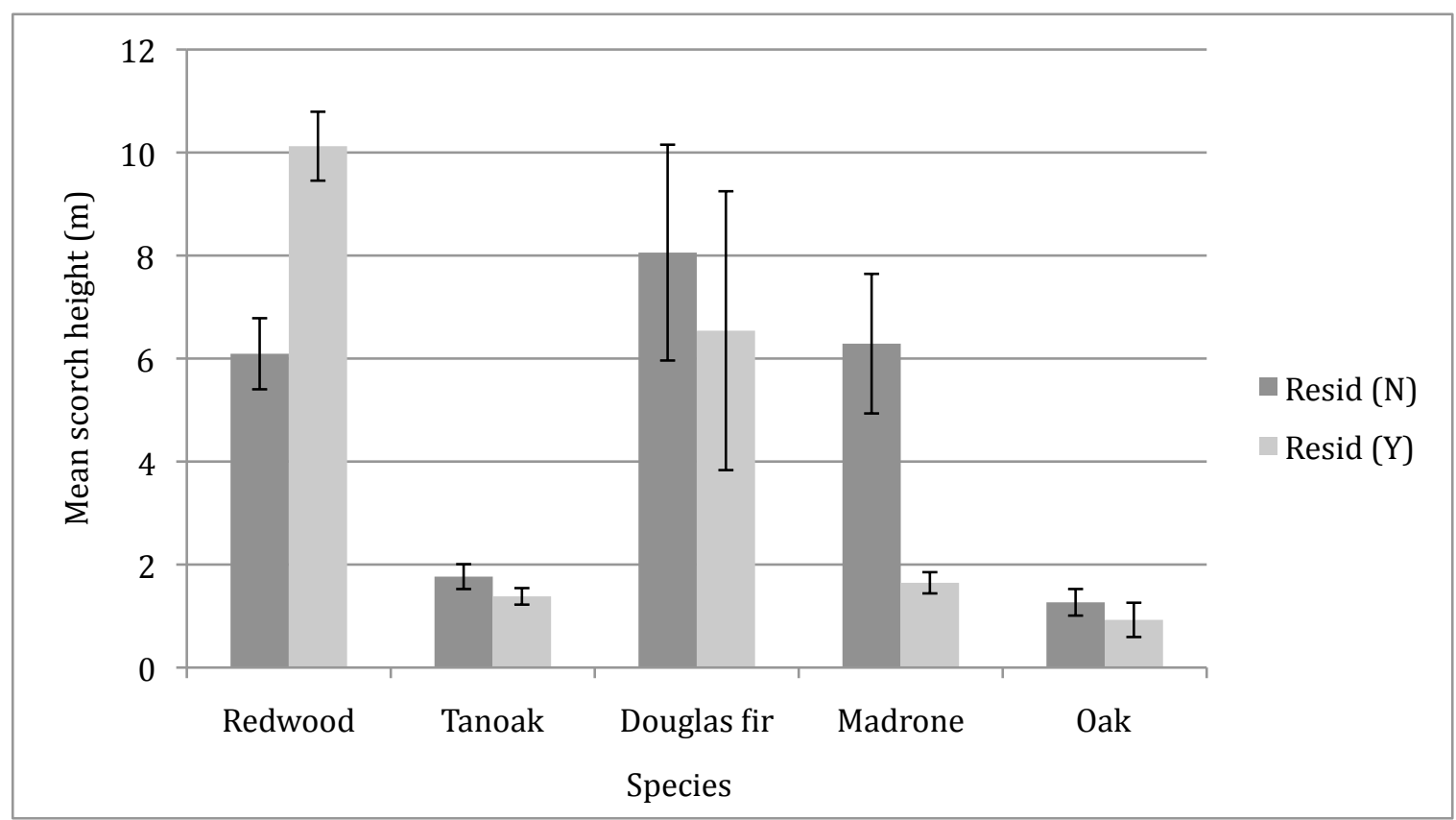

Figure 14. Comparison of scorch height (mean +- SE) of trees without and with residual canopy for five most common trees species on three sites in the Santa Cruz Mountains. Redwood t-test results: $\mathrm{t}=-4.031, \mathrm{df}=316.0, \mathrm{p}<0.001$. Madrone $\mathrm{t}$-test results: $\mathrm{t}=3.387$, $\mathrm{df}=15.637, \mathrm{p}=0.004$.

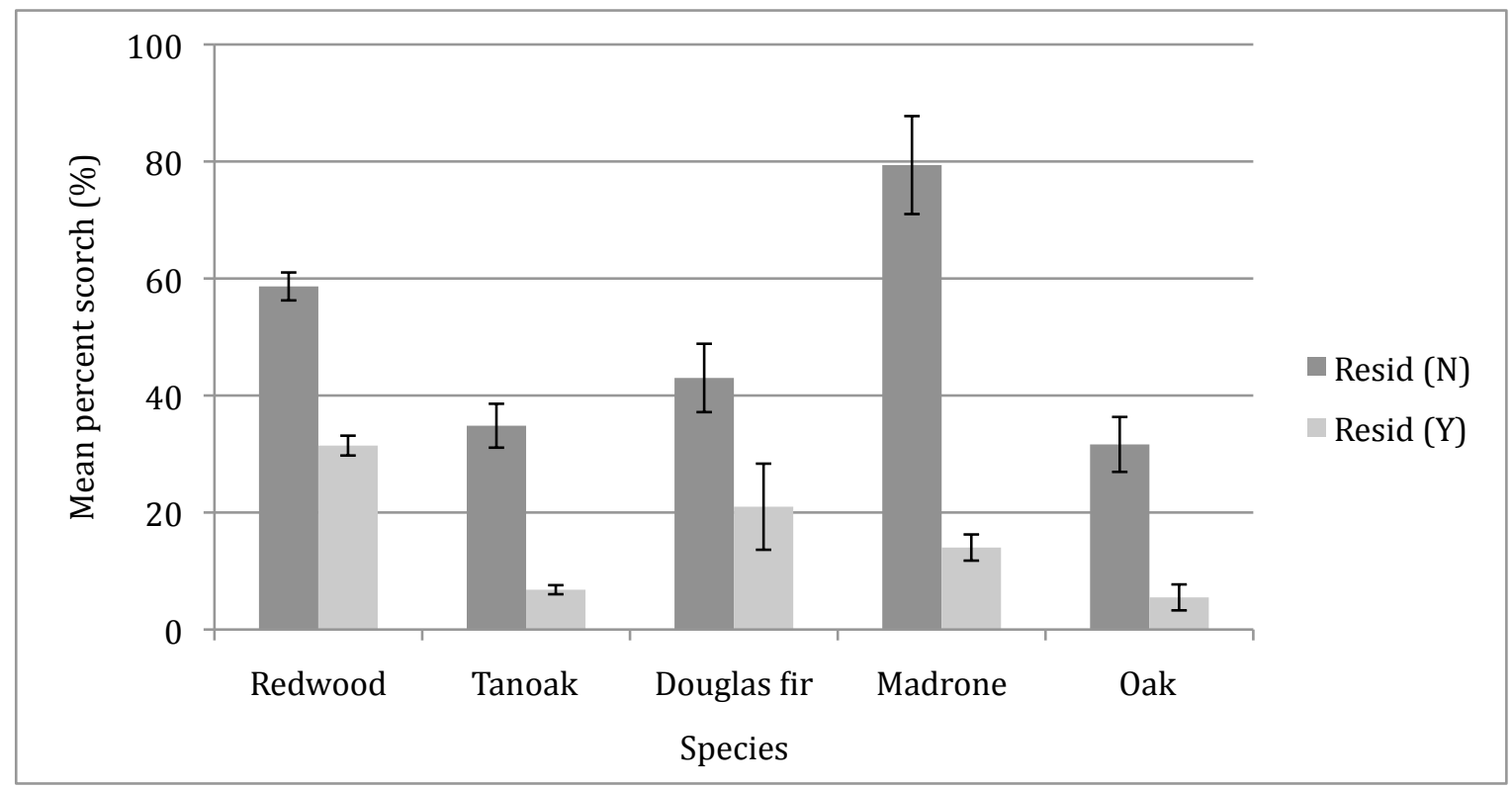

Figure 15. Comparison of percent scorch (mean \%+- SE) on trees without and with residual canopy for the five most common tree species on three sites in the Santa Cruz Mountains. Redwood t-test results: 9.362, $\mathrm{df}=307.873, \mathrm{p}<0.001$. Tanoak t-test results: $\mathrm{t}=7.320, \mathrm{df}=100.587, \mathrm{p}<0.001$. Madrone $\mathrm{t}$-test results: $\mathrm{t}=7.544, \mathrm{df}=16.583, \mathrm{p}<0.001$. Oak t-test results: $\mathrm{t}=5.038, \mathrm{df}=34.279, \mathrm{p}<0.001$. 
Table 3. Comparison of mean tree height of five most common tree species with and without post-fire residual canopy on three sites in the Santa Cruz Mountains.

\begin{tabular}{|l|l|l|l|l|l|}
\hline Species & $\begin{array}{l}\text { Mean tree } \\
\text { height with } \\
\text { residual } \\
\text { canopy +- SE } \\
(\mathrm{m})\end{array}$ & $\begin{array}{l}\text { Mean tree } \\
\text { height without } \\
\text { residual } \\
\text { canopy +- SE } \\
(\mathrm{m})\end{array}$ & T-statistic & $\begin{array}{l}\text { Degrees of } \\
\text { freedom }\end{array}$ & P-value \\
\hline Redwood & 33.3 & 9.1 & 15.658 & 214.167 & $<0.001$ \\
\hline Tanoak & 21.3 & 6.0 & 9.951 & 45.027 & $<0.001$ \\
\hline Douglas fir & 26.1 & 16.7 & 1.470 & 19.291 & 0.158 \\
\hline Madrone & 11.9 & 7.6 & 2.657 & 8.591 & 0.027 \\
\hline Oak & 17.8 & 3.9 & 4.524 & 3.273 & 0.017 \\
\hline
\end{tabular}

Table 4. Comparison of mean DBH of five most common tree species with and without post-fire residual canopy on three sites in the Santa Cruz Mountains.

\begin{tabular}{|l|l|l|l|l|l|}
\hline Species & $\begin{array}{l}\text { Mean DBH } \\
\text { with residual } \\
\text { canopy +- SE } \\
(\mathrm{cm})\end{array}$ & $\begin{array}{l}\text { Mean DBH } \\
\text { without } \\
\text { residual } \\
\text { canopy +- SE } \\
(\mathrm{cm})\end{array}$ & T-statistic & $\begin{array}{l}\text { Degrees of } \\
\text { freedom }\end{array}$ & P-value \\
\hline Redwood & 66.5 & 16.8 & 14.235 & 200.754 & $<0.001$ \\
\hline Tanoak & 42.7 & 10.9 & 8.989 & 45.270 & $<0.001$ \\
\hline Douglas fir & 50.3 & 46.1 & 0.267 & 39.0 & 0.791 \\
\hline Madrone & 26.8 & 21.3 & 0.491 & 32.0 & 0.627 \\
\hline Oak & 52.0 & 12.7 & 4.848 & 74.0 & $<0.001$ \\
\hline
\end{tabular}

\section{Post-fire Resilience}

Regenerated canopy

Redwood had the highest percentage of trees with post-fire regeneration (Figure 16), despite having a higher mean percent scorch than most associated species. Oak, madrone, and tanoak had at least $40 \%$ of trees with regenerated canopy present. When mean scorch height of trees with and without the presence of regenerated canopy was compared, redwood, tanoak, and oak had significantly higher mean scorch height for trees with regenerated canopy. Madrone had significantly higher mean scorch on trees 
without regenerated canopy (Figure 17). Redwood and Douglas fir had significantly higher mean percent scorch for trees without regenerated canopy present (Figure 18). Redwood, tanoak, and oak each had a significantly higher mean tree height for trees with regenerated canopy than for trees without regenerated canopy (Table 5). Additionally, redwood, tanoak, madrone, and oak each had a significantly larger mean DBH for trees with regenerated canopy present than for trees without regenerated canopy (Table 6). Oak trees with regenerated canopy were found on significantly $(t=2.759, \mathrm{df}=74.0$, $\mathrm{p}=0.007$ ) steep slopes than trees without regenerated canopy. There was no correlation found between highest scorch of plot and percent total regenerated canopy.

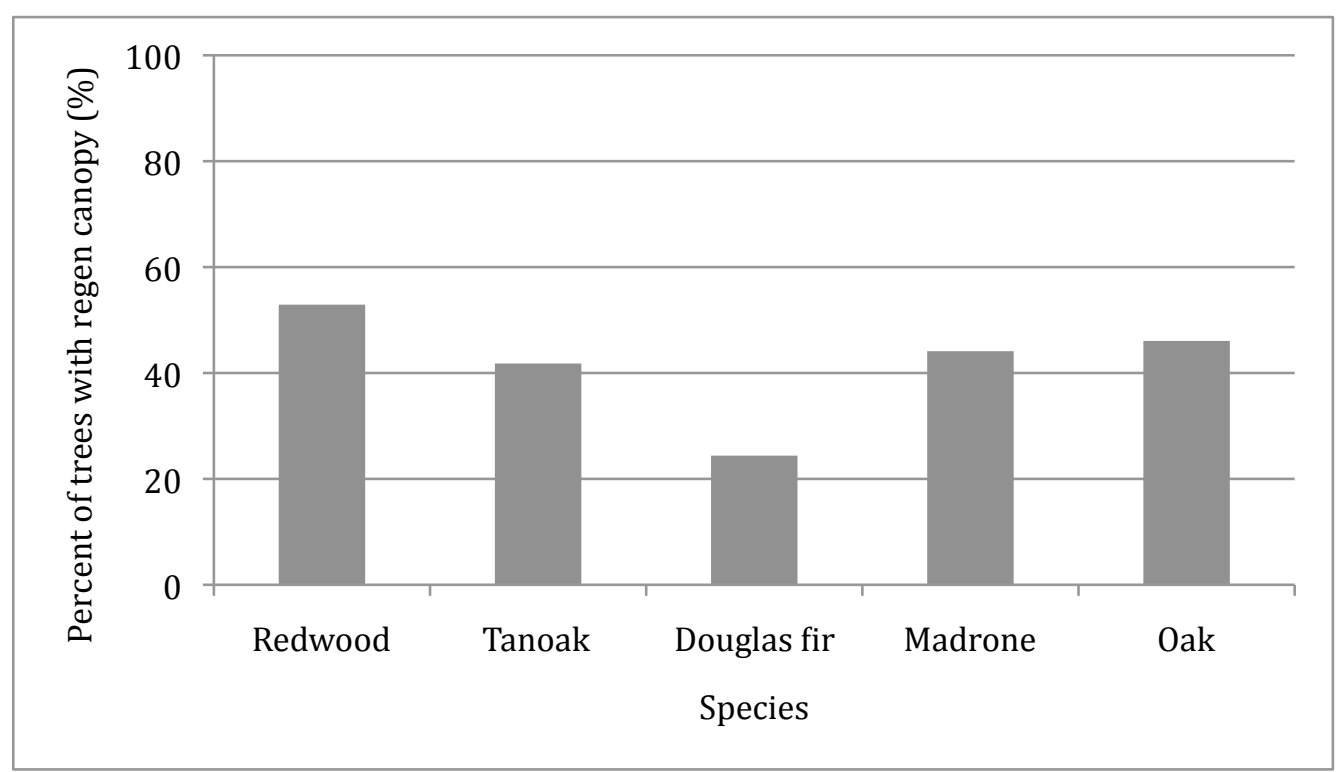

Figure 16. Percentage of trees with post-fire regenerated canopy of five most common tree species on three sites in the Santa Cruz Mountains. 


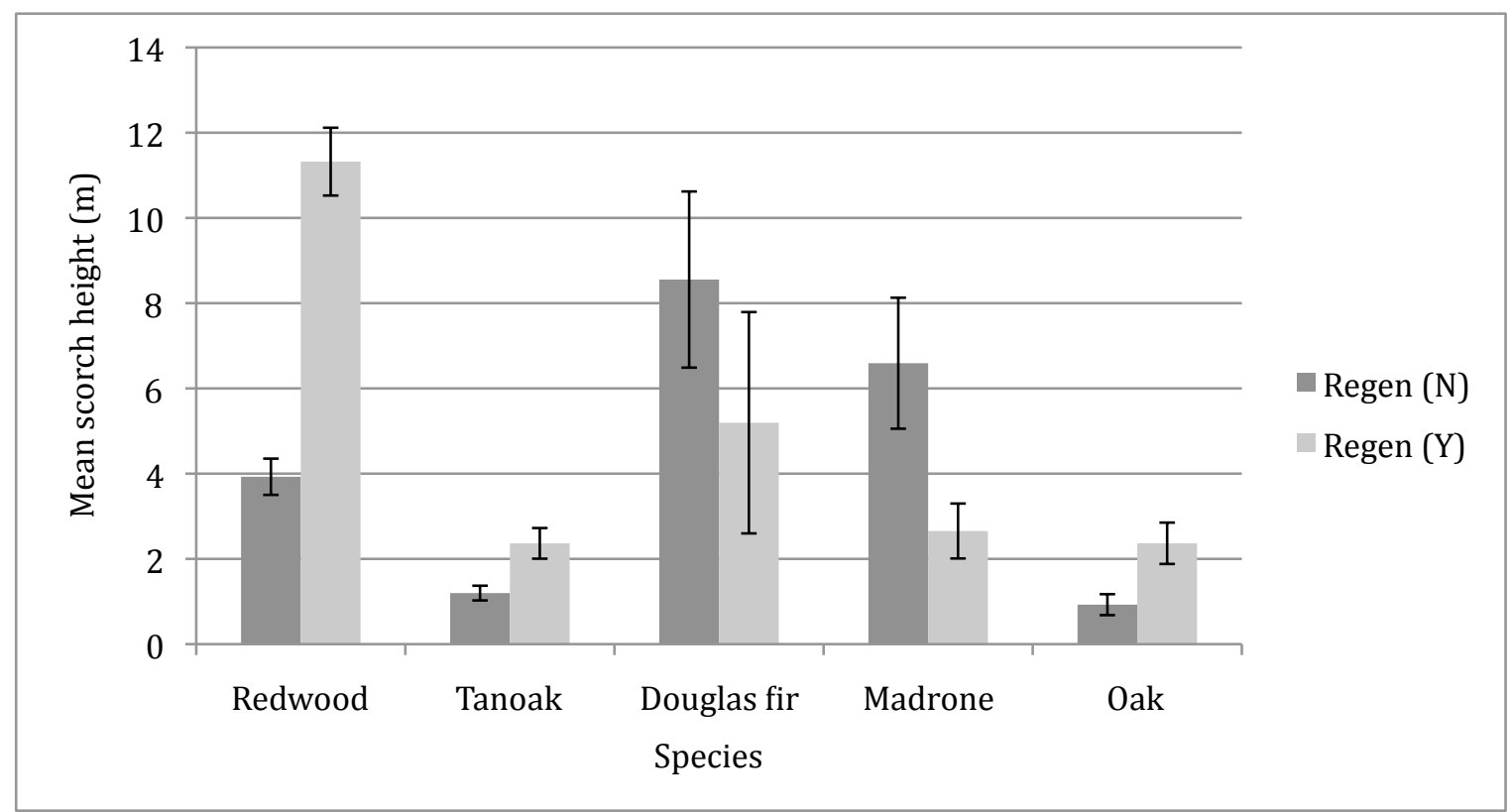

Figure 17. Comparison of scorch height (mean +- SE) of trees without and with regenerated canopy for five most common species on three sites in the Santa Cruz Mountains. Redwood t-test results: $\mathrm{t}=-8.197, \mathrm{df}=247.879, \mathrm{p}<0.001$. Tanoak t-test results: $\mathrm{t}=-3.224, \mathrm{df}=125.0, \mathrm{p}=0.002$. Madrone $\mathrm{t}$-test results: $\mathrm{t}=2.2363, \mathrm{df}=16.332$, $\mathrm{p}=0.031$. Oak t-test results: $\mathrm{t}=-2.646, \mathrm{df}=12.443, \mathrm{p}=0.021$.

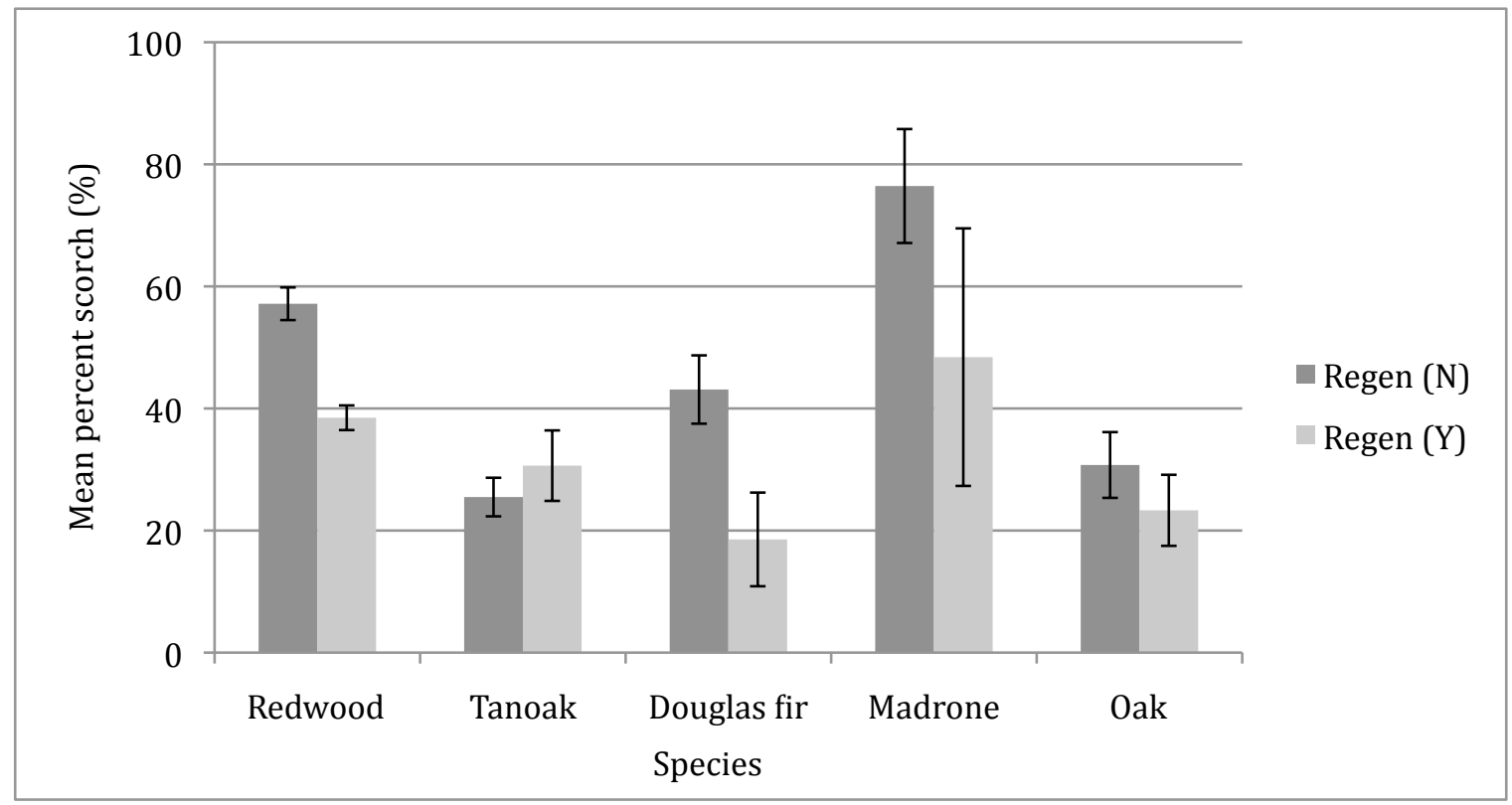

Figure 18. Comparison of percent scorch (mean \%+- SE) on trees without and with regenerated canopy for the five most common tree species on three sites in the Santa Cruz Mountains. Redwood t-test results: $\mathrm{t}=5.727, \mathrm{df}=316.0, \mathrm{p}<0.001$. Douglas fir $\mathrm{t}$-test results: $\mathrm{t}=2.094, \mathrm{df}=32.0, \mathrm{p}=0.044$. 
Table 5. Comparison of mean tree height of five most common tree species with and without post-fire regenerated canopy on three sites in the Santa Cruz Mountains.

\begin{tabular}{|l|l|l|l|l|l|}
\hline Species & $\begin{array}{l}\text { Mean tree } \\
\text { height with } \\
\text { regenerated } \\
\text { canopy +- SE } \\
(\mathrm{m})\end{array}$ & $\begin{array}{l}\text { Mean tree height } \\
\text { without } \\
\text { regenerated } \\
\text { canopy +- SE }(\mathrm{m})\end{array}$ & $\begin{array}{l}\text { T- } \\
\text { statistic }\end{array}$ & $\begin{array}{l}\text { Degrees of } \\
\text { freedom }\end{array}$ & P-value \\
\hline Redwood & 30.6 & 6.7 & 17.035 & 239.537 & $<0.001$ \\
\hline Tanoak & 15.9 & 6.0 & 6.188 & 73.946 & $<0.001$ \\
\hline Douglas fir & 24.3 & 17.8 & 0.982 & 17.062 & 0.340 \\
\hline Madrone & 8.8 & 8.1 & 0.299 & 7.958 & 0.772 \\
\hline Oak & 13.2 & 3.1 & 4.990 & 9.495 & 0.001 \\
\hline
\end{tabular}

Table 6. Comparison of mean DBH of five most common tree species with and without post-fire regenerated canopy on three sites in the Santa Cruz Mountains.

\begin{tabular}{|l|l|l|l|l|l|}
\hline Species & $\begin{array}{l}\text { Mean DBH } \\
\text { with } \\
\text { regenerated } \\
\text { canopy +- SE } \\
(\mathrm{cm})\end{array}$ & $\begin{array}{l}\text { Mean DBH } \\
\text { without } \\
\text { regenerated } \\
\text { canopy +-SE }(\mathrm{cm})\end{array}$ & $\begin{array}{l}\text { T- } \\
\text { statistic }\end{array}$ & $\begin{array}{l}\text { Degrees of } \\
\text { freedom }\end{array}$ & P-value \\
\hline Redwood & 31.0 & 6.7 & 17.981 & 258.397 & $<0.001$ \\
\hline Tanoak & 17.3 & 6.5 & 6.504 & 86.532 & $<0.001$ \\
\hline Douglas fir & 24.3 & 21.2 & 0.491 & 39.0 & 0.626 \\
\hline Madrone & 27.4 & 11.8 & 3.419 & 20.759 & 0.003 \\
\hline Oak & 28.8 & 7.1 & 6.833 & 52.967 & $<0.001$ \\
\hline
\end{tabular}

\section{Basal regeneration}

Redwood basal sprouts far out numbered basal sprouts of tanoak, madrone, and oak (Table 7). Redwood also had the highest mean number of basal sprouts per plot (Fratio $=11.522, \mathrm{df}=3, \mathrm{p}<0.001)$. There was no significant difference in the mean number of basal sprouts among tanoak, madrone, and oak (Figure 19). When site was taken into consideration there was a great deal of variability both among sites and among species. At the Martin site, none of the species had a mean number of sprouts per plot above 100 sprouts, while at the Lockheed site there was a mean of over 120 redwood sprouts per 
plot and at the Whitehurst site there was a mean of over 160 redwood sprouts per plot. Tree height, DBH, and percent scorch did not have any correlation to number of basal sprouts or number of sprouts per plot. Redwood had the highest mean number of basal sprouts per tree, and had significantly higher $(\mathrm{F}-\mathrm{ratio}=5.774, \mathrm{df}=3, \mathrm{p}=0.001)$ mean number of basal sprouts per tree than tanoak and oak. Although redwood had a higher mean number of sprouts per tree than madrone, there was not a significant difference (Figure 20). Each of the species had the highest mean number of basal sprouts per tree at the Whitehurst site. Redwood and tanoak had the lowest mean number of basal sprouts per tree at the Martin site, and madrone and oak had the lowest mean number at the Lockheed site (Figure 21). In the small size class, sprouts under 0.5 meter, there was no significant difference between the four species. In the medium class, sprouts between 0.5 meter and 1.0 meter, and the large class, sprouts over 1.0 meter, redwood had significantly more sprouts per tree than the other three species (Figure 22). Percent of tree scorched and DBH were not correlated with number of basal sprouts per tree. 
Table 7. Total number of post-fire basal sprouts of four most common species on three sites in the Santa Cruz Mountains. Douglas fir is not included, because it does not sprout.

\begin{tabular}{|l|l|l|l|l|}
\hline Site & Redwood & Tanoak & Madrone & Oak \\
\hline Martin & 1758 & 484 & 177 & 513 \\
\hline Whitehurst & 4716 & 742 & 273 & 110 \\
\hline Lockheed & 2973 & 880 & 14 & 24 \\
\hline
\end{tabular}

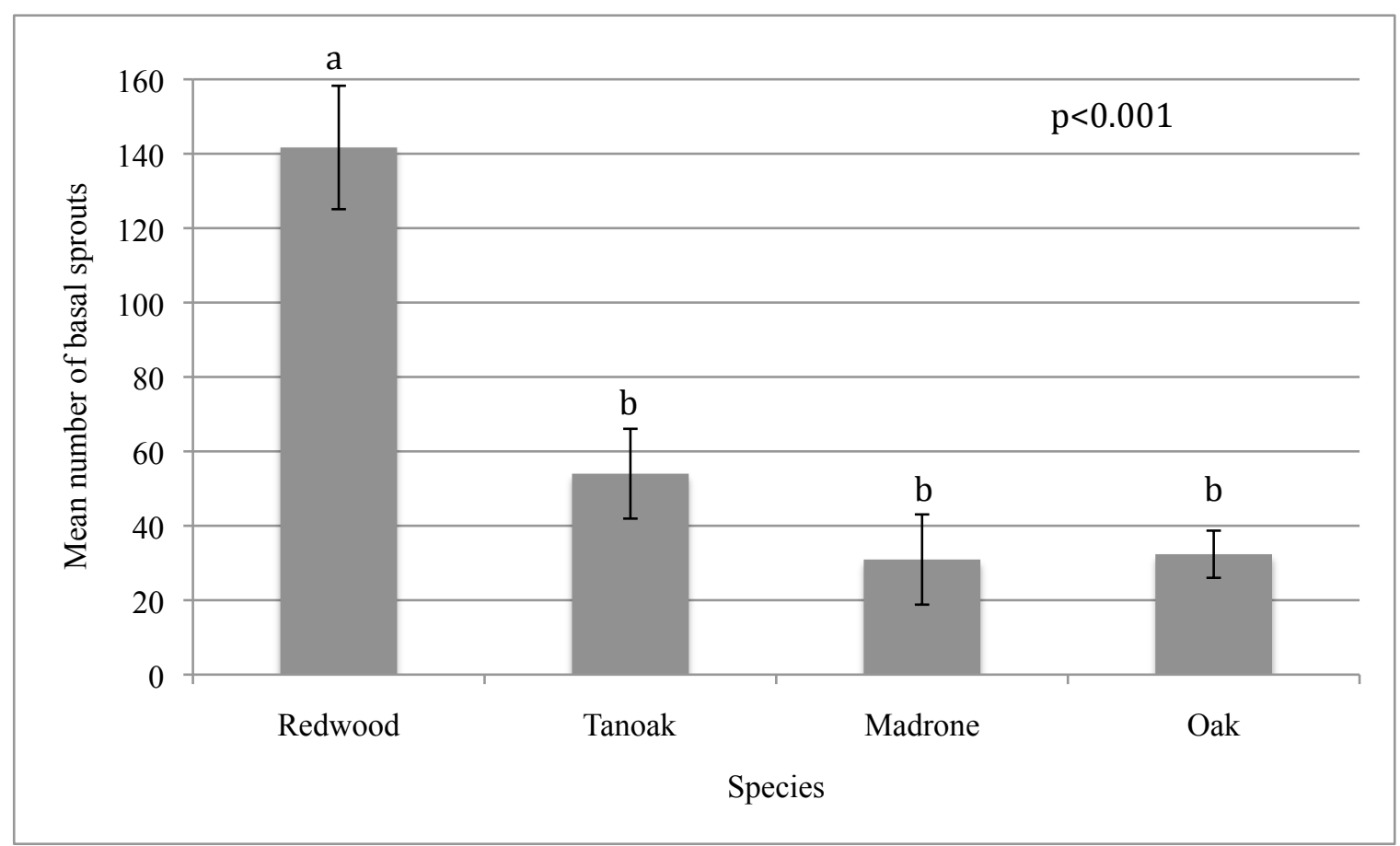

Figure 19. Number of post-fire basal sprouts per plot (mean +- SE) of four most common tree species on three sites in the Santa Cruz Mountains. Species with the same lower case letter are not significantly different from each other. 


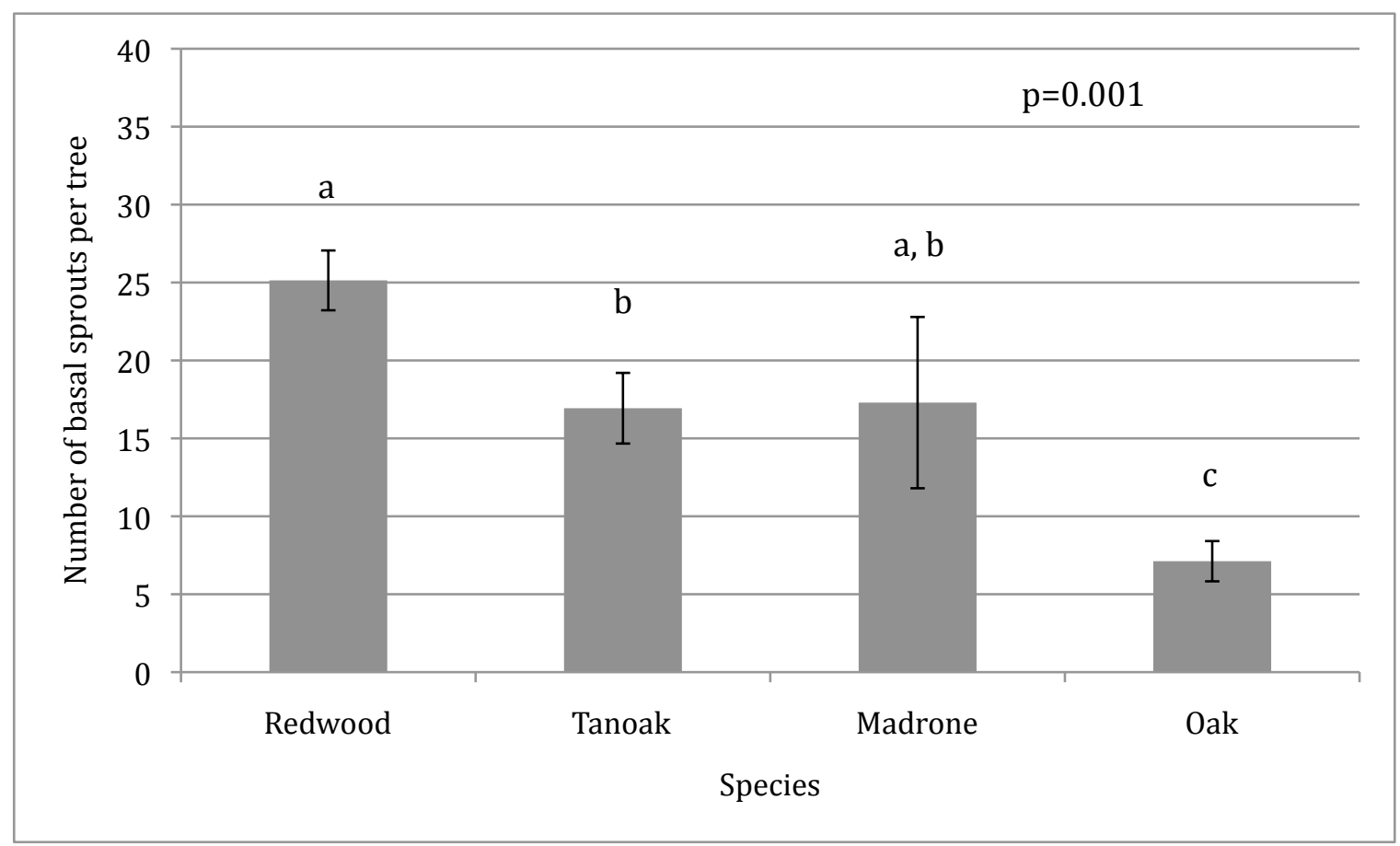

Figure 20. Number of post-fire basal sprouts per tree (mean +- SE) for four species on three sites in the Santa Cruz Mountains. Species with the same lower case letter are not significantly different from each other.

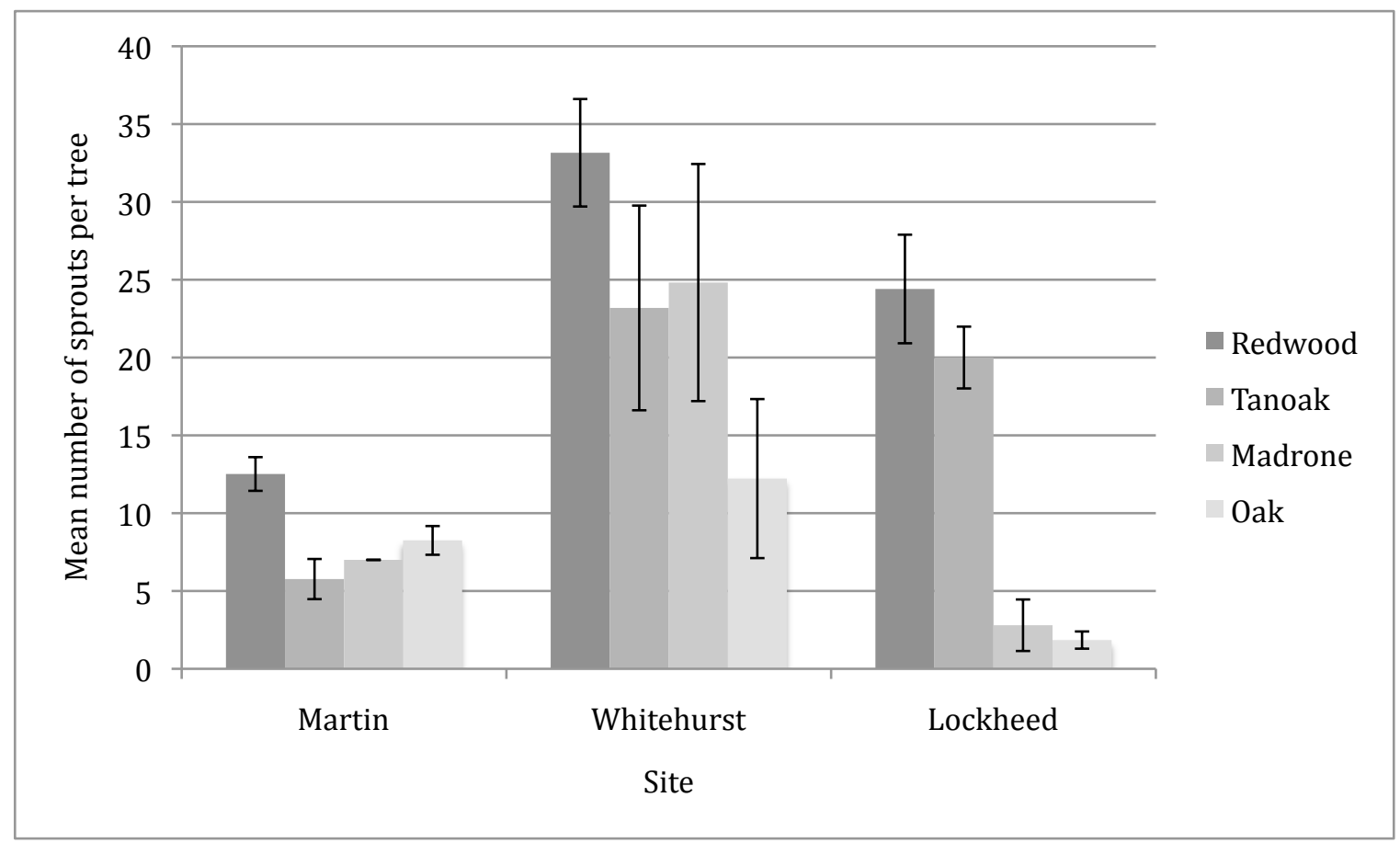

Figure 21. Number of post-fire basal sprouts per tree (mean +- SE) for four species on three sites in the Santa Cruz Mountains by site. 


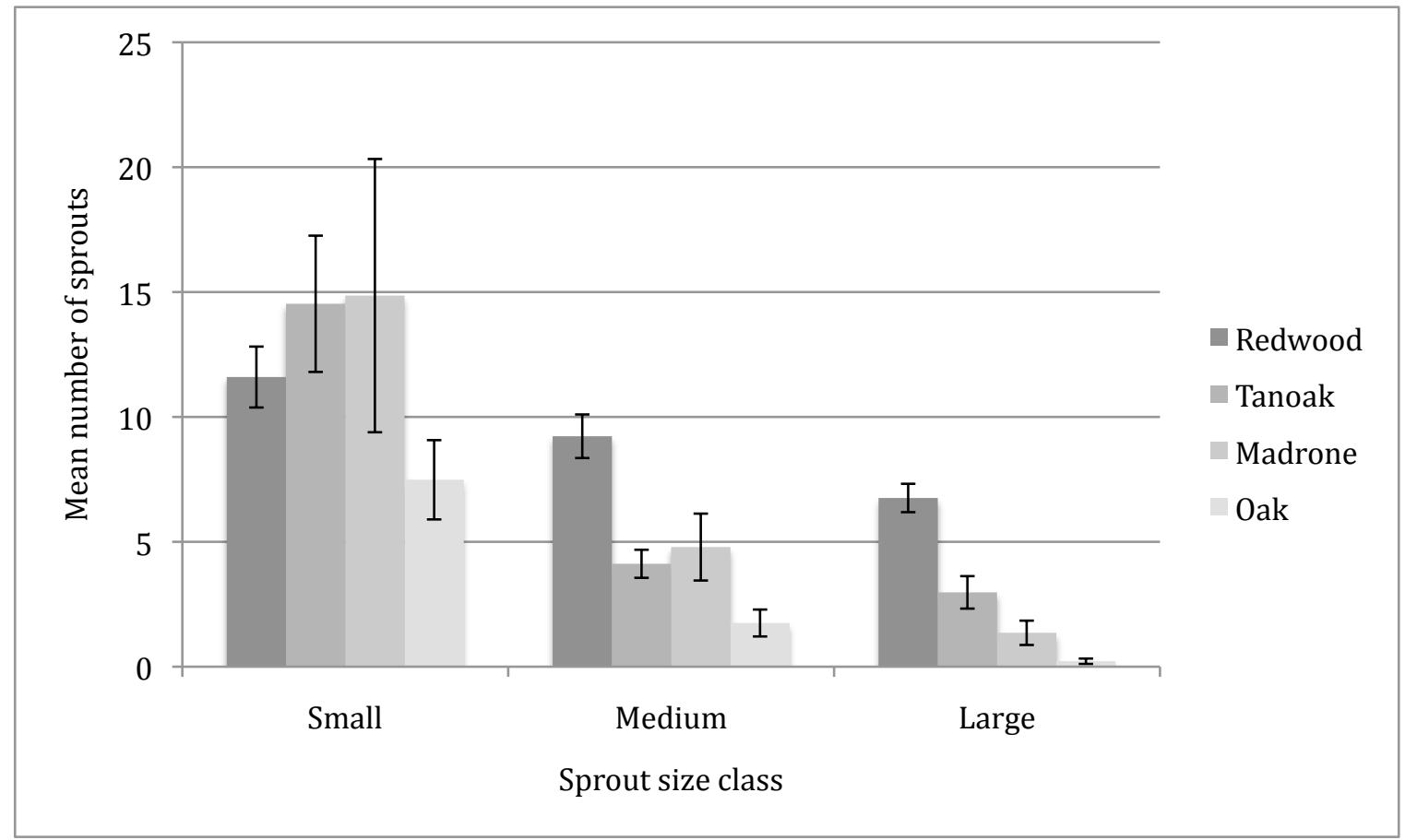

Figure 22. Number of post-fire basal sprouts per tree (mean +- SE) in three size classes on three sites in the Santa Cruz Mountains. 


\section{Post-fire seeding germination}

Overall, redwood seedlings far out numbered all other seedlings (Table 8).

Tanoak and oak seedlings were found on all three sites. Redwood seedlings were not found on the Martin site, Douglas fir seedlings were not found on the Whitehurst site, and madrone seedlings were not found on the Lockheed site. There were no Douglas fir trees sampled on the Whitehurst site, therefore it is reasonable that there would be no seedlings found either. Tanoak, Douglas fir, madrone, and oak seedlings had little variability between the three sites. However, redwood seedlings had high variability ranging from no seedlings to over 50,000 (Figure 23). There was no correlation found between number of seedlings and total canopy cover, duff depth, aspect, or slope. 
Table 8. Total number of post-fire seedlings of five most common species on three sites in the Santa Cruz Mountains.

\begin{tabular}{|l|l|l|l|l|l|}
\hline Site & Redwood & Tanoak & $\begin{array}{l}\text { Douglas } \\
\text { fir }\end{array}$ & Madrone & Oak \\
\hline Martin & 0 & 36 & 13 & 2 & 24 \\
\hline Whitehurst & 50189 & 11 & 0 & 32 & 7 \\
\hline Lockheed & 55 & 3 & 18 & 0 & 7 \\
\hline Total & 50244 & 50 & 31 & 34 & 38 \\
\hline
\end{tabular}

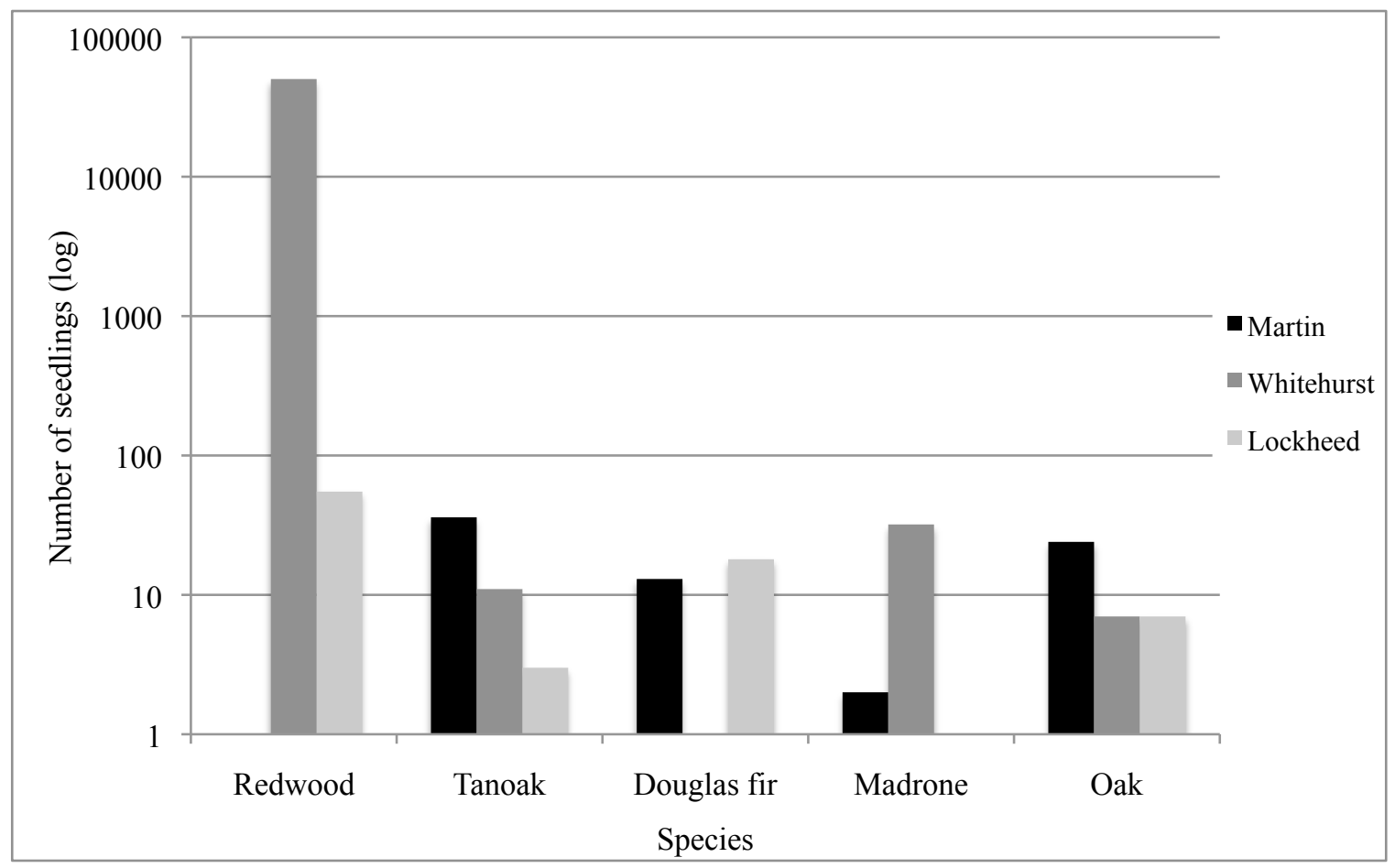

Figure 23. Number of post-fire seedlings of five most common tree species on three sites in the Santa Cruz Mountains. Number is represented in log notation. 


\section{DISCUSSION}

Coast redwood was the dominant species at each of the three sites sampled for

this study. Redwood trees were also the tallest and had some of the highest scorch marks. This study showed that, compared to the other four dominant tree species (tanoak, Douglas fir, madrone, and oak), redwood trees were more resistant to fire. Redwoods had the highest overall survival, although not significantly higher than tanoak or madrone, and significantly greater crown survival than the four associated tree species. Redwoods also had more residual canopy than associated tree species. These findings are consistent with the findings of Ramage, O’Hara, and Caldwell (2010), who found that redwoods had higher trunk survival than tanoaks, especially at higher fire severities. However, Finney and Martin (1993) found that few trees larger than 25 centimeters DBH were top killed, while in this study, roughly $11 \%$ of trees larger than 25 centimeters DBH had crown mortality (i.e. top killed) and the largest redwood tree in this study that had crown mortality was 81.2 centimeters DBH. The reason for this discrepancy may be that Finney and Martin (1993) examined prescribed fire, while this study examined wildfire including some stands with crown fire. Both Agee (1993) and Scanlon (2007) observed that larger, mature redwoods survive low to moderate fire, but may perish in higher intensity fires.

Redwood trees were also more resilient after fire than the associated tree species. Redwood had greater canopy regeneration and greater basal regeneration than the other four species. Over $50 \%$ of redwood trees had some regenerated canopy present, while over $40 \%$ of tanoak, madrone, and oak had some regenerated canopy. Redwood, tanoak, 
and oak trees each had a higher mean tree height and a larger mean DBH for trees with regenerated canopy than without. For these species, this suggests that taller and larger trees have a better chance of having canopy regenerate after a fire. This finding is consistent with Ramage, O'Hara, and Caldwell (2010) who noted that even with 100\% scorch, larger redwood trees often had vigorous canopy regeneration. These researchers also found that one year post-fire tanoak had a slight advantage over redwood in terms of basal sprouting. However, in the Santa Cruz Mountains redwood had the highest mean number of sprouts per tree, although it was not significantly higher than madrone's mean number of sprouts per tree. Redwood had more medium and large sprouts than the other three species. Although redwood did not have significantly more sprouts per tree than madrone, the fact that it had more medium and large sprouts shows that it clearly had more prolific regeneration. The inconsistency with Ramage, O'Hara, and Caldwell (2010) could be caused by differing methodologies, environmental differences, or differing lapsed time since the fires. The lack of significant correlation between tree height and DBH and basal sprouting suggests that although larger redwood trees have a better chance of crown retention and regeneration, larger redwood trees do not necessarily have more basal regeneration following fire. Redwood also had a higher number of basal sprouts per plot, which is mostly likely due to the fact that redwoods make up a larger part of the forest composition than the other sprouting species.

One unexpected finding that did not support hypothesis number two was that redwood seedlings far outnumbered tanoak, Douglas fir, madrone, and oak seedlings. Typically, seedlings are a minor component of redwood regeneration. This was true of 
the Martin and Lockheed sites, which had a total of 0 and 55 redwood seedlings, respectively. However, the Whitehurst site was unusual in the fact that a total of 50,244 coast redwood seedlings were found in the sampling plots. The number of tanoak, Douglas fir, madrone, and quercus seedlings was in the range expected. On some plots, seedlings were found when there were no trees of that species in the plot.

Duff depth, aspect, slope, and canopy cover were not correlated with the number of seedlings of any species, suggesting that some other factor may be influencing seedling germination on these sites post-fire.

One possibility is seed predation. Post-dispersal seed predation may affect the number of viable seeds available for germination. Predation ranges in severity. Animals that collect and eat seeds may also act as seed dispersers, if the seeds are not destroyed during digestion (Janzen 1971). Zwolak et al. (2010) found that deer mice predate on Douglas fir and ponderosa pine seeds in recently burned areas, and suggests that post-fire regeneration and recruitment may be substantially influenced by consumers (Zwolak et al. 2010). Sullivan (1979) found that in Douglas fir forests, deer mice had destroyed 95\% of Douglas fir seeds within three days of beginning a controlled experiment (Sullivan 1979). Tanoak acorns, madrone seeds, and oak acorns are also heavily predated. Animals and birds often transport the seeds of these species great distances (McDonald and Tappeiner 1990; Tappeiner, McDonald, and Roy 1990; Thornburgh 1990). While no redwood seed predation studies have been published, it is possible that seed predation may be affecting the numbers of seedlings on these sites. It is possible that a lack of seed 
predators causes increases in the number or redwood seedlings, or that over predation may cause a decrease in redwood seedlings.

Gravity may also play a role in seed dispersal. The seeds of all five species in this study typically fall directly under or close to the tree crown. However, madrone, tanoak, an oak seeds are known to roll down steeper slopes (McDonald and Tappeiner 1990; Tappeiner, McDonald, and Roy 1990; Thornburgh 1990). Redwood seeds are small and light and do not have a wing (Olson Jr., Roy, and Walters 1990). Wind dispersal is typically limited, and gravity dispersal may be limited as well.

The three sites had different soils, distances from the ocean, amounts of localized fog, and elevations. Any combination of these variables may explain the extreme range of redwood seedlings. 


\section{IMPLICATIONS}

In Fire Ecology of Pacific Northwest Forests, Agee (1993) defines three types of

fire: surface fire, understory fire, and crown fire range from lowest to highest in intensity and fuel consumption. Surface fire behavior is the most predictable. Surface fires are easier and safer for fire fighters to control. This study found that in plots with redwood trees present the likelihood of stand replacing crown fire was less than in plots without redwood trees present. For fire fighters, this means that it may be easier and safer to control fires that occur in redwood stands compared to fires that occur in other forest types.

There are also ecological differences following stand replacing fire and fires where there is some crown retained. First, surviving crown provides an interception surface (Burgess and Dawson 2004; Dawson 1998) reducing soil erosion. When precipitation falls directly on soil, small particles and pieces of soil matter can be loosened and washed away (Biswell 1989). More canopy cover surviving after a fire, such as at the Martin and Whitehurst sites, means that more precipitation will be prevented from directly hitting soils on the forest floor. Second, redwood forests provide habitat for a variety of plants and animals. Amphibians, reptiles, a variety of birds, more than 60 species of mammals, and many invertebrates inhabit the canopy and forest floor of redwood stands (Baker et al. 2006; Barbour et al. 2001; Brand and George 2001; Gellman and Zielinski 1996; Noss 2000; Willett 2001). Post-fire canopy continues to provide shelter and food for these species. Third, canopy cover provides shade and wind protection for creeks and streams. Without this important ecological service, fish and 
invertebrates that live in creeks and streams can be affected by increasing water temperatures, and reduced organic inputs (Knight and Bottorff 1984). Last, stand replacing fire results in even aged forests. Repeated surface and understory fire, as well as other small scale disturbances, increases ecological heterogeneity (Lorimer et al. 2009). In the sample areas of this study that had significantly higher crown survival, these ecological services and characteristics were more likely to remain intact than in the areas that had lower crown survival.

In light of these benefits, protecting, conserving, and restoring coast redwood forests is important to reducing intense wildfires. Recently, using thinning as a management tool to reduce fire hazard is becoming more popular (Russell 2010). However, the results of this study suggest that thinning, particularly of mature redwood trees, may not be an effective strategy in coast redwood forests. Thinning can create canopy gaps; redwood regeneration often occurs along gap edges (Busing and Fujimori 2002) increasing the production of smaller more fire prone stems. In terms of tree height and $\mathrm{DBH}$, the results of this study show that taller, larger trees survive and regenerate better after fire than smaller trees. This is substantiated by Finney and Martin (1993) and Ramage, O'Hara, and Caldwell (2010), as well as by many anecdotal accounts such as Agee (1993) and Scanlon (2007). A fire subsequent to thinning could have a higher mortality rate due an increase in small trees. Additionally, basal sprouting after thinning creates a clumped growth pattern. Finney and Martin (1993) suggest that trees growing in clumps, also called fairy rings, may have a higher risk of damage and death. 


\section{FUTURE RESEARCH}

The next step is to evaluate survivorship and regeneration on a larger scale. Analyzing data from more sites that cover a greater portion of the southern redwood region will give a clearer understanding of how redwoods and associated species respond to fire. Additionally, studies are needed to evaluate long-term effects of fire in the southern redwood forests. This study, as well as Ramage, O’Hara, and Caldwell (2010), assess short-term responses to fire in the southern redwood region, but there are no known long-term studies of redwood and associated species' response to fire in the southern region.

Future work on seedling germination and survival should focus on soils and management. Soils were not analyzed as part of this study. However, there were some obvious differences between the three study sites that may be related to seedling growth. The Martin site is largely dominated by well-drained sandy soils. The sandy soils of the Bonny Doon Ecological Reserve, the site of the Martin Fire, could have inhibited redwood seedling growth. There were many ponderosa pine, knobcone, tanoak, and oak seedlings but not a single redwood seedling. The Whitehurst site was relatively flat with a thicker duff layer. The Lockheed site consisted of gravelly soil on steeper slopes. Management techniques and land use may also affect the number of seedlings. The Martin site allows mixed, low impact recreational users, the Whitehurst site does not allow off trail use, and the Lockheed site has active timber-harvest activities. A combination of differing soils and differing human impact may be influencing the 
number and vigor of seedlings. Also, long-term seedling survival in areas of varying soil types and management activities should be investigated.

Another potential avenue for future research is a detailed study of redwood

dominance and regeneration. During the course of this study it was observed that in areas of high scorch height, indicating high flame length, redwood trees were most common and regeneration was flourishing. While this study indicates that the coast redwoods in the Santa Cruz Mountains are more resistant to fire and more resilient after fire than associated species, the dominance of redwood trees and regeneration of associated trees was not investigated. 


\section{REFERENCES}

Agee, James K. 1993. Fire Ecology of the Pacific Northwest Forests. Washington D. C.: Island Press.

. 1996. Fire regimes and approaches for determing fire history. Ogden, UT:

U.S. Department of Agriculture, Forest Service, Intermountain Research Station.

Alexander, Earl B. and John O. Sawyer. 1997. Ecological subregions of California: Section and subsection descriptions. Ed Scott R. Miles and Charles B. Goudey. R5-EM-TP-005: USDA, U.S. Forest Service, Pacific Southwest Region.

Allen-Diaz, Barbara, Richard Standiford, and Randall D. Jackson. 2007. Oak woodland and forests. In Terrestrial vegetation of California, ed. Michael G. Barbour, Todd Keeler-Wolf and Allan A. Schoenherr:313-338. Berkeley, CA: University of California Press.

Anderson, M. Kat. 2005. Tending the wild: Native American knowledgee and the management of California's natural resources. Berkeley: University of California Press.

Arno, Stephen F. and Steven Allison-Bunnell. 2002. Flames in our forest: Disaster or renewal? Washington D. C.: Island Press.

Azevedo, J. and D. L. Morgan. 1974. Fog precipitation in coastal California forests. Ecology 55, no. 5.

Baker, Lauren M., M. Zachariah Peery, Esther E. Burkett, Steven W. Singer, David L. Suddjian, and Steven R. Beissinger. 2006. Nesting habitat characteristics of the marbled murrelet in central California redwood forests. Journal of Wildlife Management 70: 939-946.

Barbour, Michael G. 2007. Closed-cone pine and cypress forests. In Terrestrial vegetation of California, ed. Michael G. Barbour, Todd Keeler-Wolf and Allan A. Schoenherr:296-312. Berkeley, CA: University of Callifornia Press.

Barbour, Michael, Sandy Lydon, Mark Borchert, Marjorie Popper, Valerie Whitworth, and John Evarts. 2001. Coast Redwoods: A natural and cultural history. Ed John Evarts and Marjories Pooper. Los Olivos, CA: Cachuma Press.

Beames, Miriam. 2008. Bonny Doon Eco Reserve fire aftermath. The Highlander: The Rural Bonny Doon Association Newsletter. 
Biswell, Harold. 1989. Prescribed burning in California wildlands vegetation management. Berekley: University of California Press.

Brand, L. Arianna and T. Luke George. 2001. Response of passerine birds to forest edge in coast redwood forest fragments. The Auk 118: 678-686.

Brower, James E., Jerrold H. Zar, and Carl N. von Ende. 1998. Field and laboratory methods for general ecology. Boston, Massachusetts: WCB/McGraw-Hill.

Brown, James K. and Jane Kapler Smith, eds. 2000. Wildland fire in ecosystems: effects of fire on flora. Ogden, UT: U.S. Department of Agriculture, Forest Service, Rocky Mountain Research Station

Brown, P. M. and W. T. Baxter. 2003. Fire history in coast redwood forests of the Mendocino Coast, California. Northwest Science 77, no. 2: 147-158.

Brown, P. M., M. W. Kaye, and D. Buckley. 1999. Fire history in Douglas-fir and coast redwood forests at Point Reyes National Seashore, California. Northwest Science 73, no. 3: 205-216.

Brown, Peter M. and Thomas W. Swetnam. 1994. A cross-dated fire history from coast redwood near Redwood National Park, California. Canadian Journal of Forest Research 24: 21-31.

Burgess, S. S. O. and T. E. Dawson. 2004. The contribution of fog to the water relations of Sequoia sempervirens (D. Don): foliar uptake and prevention of dehydration. Plant Cell and Environment 27, no. 8: 1023-1034.

Busing, R. T. and T. Fujimori. 2002. Dynamics of composition and structure in an old Sequoia sempervirens forest. Journal of Vegetation Science 13, no. 6: 785-792.

CALFIRE. 2004. California Department of Forestry and Fire Protection fire management plan: San Mateo/Santa Cruz Unit, California Northern Region.

Dawson, T. E. 1998. Fog in the California redwood forest: ecosystem inputs and use by plants. Oecologia 117, no. 4: 476-485.

Diekmann, Lucy, Lee Panich, and Chuck Striplen. 2007. Native American management and legacy of working landscapes in California: Western landscapes were working long before Europeans arrived. Rangelands 29, no. 3: 46-50. 
Douhovnikoff, Vladimir, Adelaide M. Cheng, and Richard S. Dodd. 2004. Incidence, size, and spatial structure of clones in second-growth stands of coast redwood, Sequoia sempervirens (Cupressaceae). American Journal of Botany 91, no. 7: 1140-1146.

Finney, M. A. and R. E. Martin. 1989. Fire history in a Sequoia-sempervirens forest at Salt-Point-State-Park, California. Canadian Journal of Forest Research-Revue Canadienne De Recherche Forestiere 19, no. 11: 1451-1457.

1993. Modeling effects of prescribed fire on young-growth coast redwood trees. Canadian Journal of Forest Research-Revue Canadienne De Recherche Forestiere 23, no. 6: 1125-1135.

Finney, Mark A. and Robert E. Martin. 1992. Short fire intervals recorded by redwoods at Annadel State Park, California. Madrono 39, no. 4: 251-262.

Forest management plan for Swanton Pacific Ranch. 1991. Big Creek Lumber.

Gellman, S.T. and William J. Zielinski. 1996. Use by bats of old-growth redwood hollows on the north coast of California. Journal of Mammalogy 77: 255-265.

Greenlee, Jason M. and Jean H. Langenheim. 1990. Historic fire regimes and their relation to vegetation patterns in the Monterey Bay Area of California. American Midland Naturalist 124, no. 2: 239-253.

Griffin, James R. 1964. Isolated Pinus ponderosa forests on sandy soils near Santa Cruz, California. Ecology 45, no. 2: 410-412.

Hermann, Richard K. and Denis P. Lavender. 1990. Pseudotsuga menziesii (Mirb.) Franco: Douglas-Fir. In Silvics of North America: 1. Conifers, 2. Hardwoods, Agricultural Handbook 654, ed. Russell M. Burns and Barbara H. Honkala, tech. coords., 1. Washington D.C.: U.S. Department of Agriculture, Forest Service.

Highlander, The. 2006a. Eco reserve fire danger brushed off. The Highlander: The Rural Bonny Doon Association Newsletter. . 2006b. Fire safety in the Ecological Reserve. The Highander: The Rural Bonny Doon Association Newsletter. .2006c. Hot news about the Eco Reserve fire fuel reduction. The Highlander: the Rural Bonny Doon Association Newsletter.

Hunter, J. C. and V. T. Parker. 1993. The disturbance regime of an old-growth forest in coastal California. Journal of Vegetation Science 4: 19-24. 
Jacobs, Diana F., Dana W. Cole, and Joe R. McBride. 1985. Fire history and perpetuation of natural coast redwood ecosystems. Journal of Forestry 83, no. 8.

Janzen, Daniel H. 1971. Seed predation by animals. Annual Review of Ecology and Systematics 2: 465-492.

Keator, Glenn. 2002. Introduction to trees of the San Francisco Bay region. Ed Phyllis M. Faber and Bruce M. Pavlik. California Natural History Guides. Berkeley: University of California Press.

.2009. California plant families: West of the Sierran crest and deserts. Berkeley: University of California Press.

Kluse, Jennifer and Daniel F. Doak. 1999. Demographic performance of a rare California endemic, Chorizanthe pungens var. hartwegiana (Polygonaceae). American Midland Naturalist 142: 244-256.

Knight, Allen W. and Richard L. Bottorff. 1984. The importance of riparian vegetation to stream ecosystems. In California riparian systems: Ecology, conservvation, and productive management ed. Richard E. Warner and Kathleen M Hendrix:160-167. Berkeley: University of California Press.

Kobziar, L., J. Moghaddas, and S. L. Stephens. 2006. Tree mortality patterns following prescribed fires in a mixed conifer forest. Canadian Journal of Forest ResearchRevue Canadienne De Recherche Forestiere 36, no. 12: 3222-3238.

Koch, George W., Stephen C. Sillett, Gregory M. Jennings, and Stephen D. Davis. 2004. The limits to tree height. Nature 428.

Korhonen, Lauri, Kari T. Korhonen, Miina Rautiainen, and Pauline Stenberg. 2006. Estimation of forest canopy cover: a comparison of field measurement techniques. Silva Fennica 40, no. 4: 577-588.

Kroeber, Alfred Louis. 1976. Handbook of the Indians of California. New York: Courier Dover Publications.

Kuljian, Howard and J. Morgan Varner. 2010. The effects of sudden oak death on foliar moisture content and crown fire potential in tanoak. Forest Ecology and Management 259: 2103-2110.

Lanner, Ronald M. 1999. Conifers of California. Los Olivos, CA: Cachuma Press. 
Lorimer, Craig G, Daniel J. Porter, Mary Ann Madej, John D. Stuart, Stephen D. Jr. Veirs, Steven P. Norman, Kevin L. O'Hara, and William J. Libby. 2009. Presettlement and modern disturbance regimes in coast redwood forests: Implications for the conservation of old-growth stands. Forest Ecology and Management 258: 1038-1054.

McDonald, Philip M. and John C. Tappeiner. 1990. Arbutus menziesii Pursh: Pacific madrone. In Silvics of North America: 1. Conifers, 2. Hardwoods, Agricultural Handbook 654 ed. Russell M. Burns and Barbara H. Honkala, tech. coords., 2. Washington D.C.: U.S. Department of Agriculture, Forest Service.

McGraw, Jodi. 2004. The Sandhills conservation and management plan: A strategy for preserving native biodiversity in the Santa Cruz Sandhills. Prepared for The Land Trust of Santa Cruz County.

McGraw, Jodi M and Anna L. Levin. 1998. The roles of soil type and shade intolerance in limiting the ditribution of the edaphic endemic Chorizanthe pungens var. hartwegiana (Polygonaceae). Madrono 45, no. 2: 119-127.

McKee, Arthur. 1990. Giant chinquapin (Castanopsis chrysophylla (Dougl-) A.DC. ). In Silvics of North America: 1. Conifers, 2. Hardwoods, Agricultural Handbook 654 ed. Russell M. Burns and Barbara H. Honkala, tech. coords., 2. Washington D.C.: U.S. Department of Agriculture, Forest Service.

McPherson, Brice A., Sylvia R. Mori, David L. Wood, Andrew J. Storer, Pavel Svihra, N. Maggie Kelly, and Richard B. Standiford. 2005. Sudden oak death in California: Disease progression in oaks and tanoks. Forest Ecology and Management 213: 71-89.

Natural Resources Conservation Service. 2009. Web Soil Survey. Natural Resources Conservation Service. United States Department of Agriculture. Available at http://websoilsurvey.nrcs.usda.gov/. Acessed January 12, 2011.

Noss, Reed F., ed. 2000. The redwood forest: History, ecology, and conservation of the Coast Redwoods. Washington D.C: Island Press.

Oliver, William W. and Russell A. Ryker. 1990. Ponderosa pine (Pinus ponderosa Dougl. ex Laws.). In Silvics of North America: 1. Conifers, 2. Hardwoods, Agricultural Handbook 654 ed. Russell M. Burns and Barbara H. Honkala, tech. coords., 1. Washington D.C.: U.S. Department of Agriculture, Forest Service. 
Olson Jr., David F., Douglas F. Roy, and Gerald A. Walters. 1990. Sequoia semervirens (D. Don) Endl.: Redwood. In Silvics of North America: 1. Conifers, 2.

Hardwoods, Agricultural Handbook 654, ed. Russell M. Burns and Barbara H. Honkala, tech. coords., 1. Washington D.C.: U.S. Department of Agriculture, Forest Serivice.

Oneal, Christopher B., John D. Stuart, Steven J. Steinberg, and Lawrence Fox III. 2006. Geographi analysis of natural fire rotation in the California redwood forest during the suppression era. Fire Ecology 2, no. 1: 73-99.

Pavlik, Bruce M., Pamela Muick, Sharon G. Johnson, and Marjorie Popper. 2006. Oaks of California. Los Olivos, CA: Cachuma Press.

Plumb, Timothy R. and Philip M. McDonald. 1981. Oak management in California. Berkeley, CA: U.S. Department of Agriculture, Forest Service, Pacific Southwest Forest and Range Experiment Station.

Pritzker, Barry. 2000. A Native American encyclopedia: History, culture, and peoples. Oxford: Oxford University Press.

Ramage, B. S., K. L. O'Hara, and B. T. Caldwell. 2010. The role of fire in the competitive dynamics of coast redwood forests. Ecosphere 1, no. 6: 1-18.

Reid, Margery and Stewart Thompson. 1996. Ecological fieldwork methods. In Essential Environmental Science: Mehtods and Techniques, ed. Simon Watts and Lyndsay Halliwell:357-388. London: Routledge.

Russell, Will. 2010. The influence of industrial forest management interests on forest restoration and carbon sequestration policy and practice. The International Journal of Environmental, Cultural, Economic, and Social Sustainablity 6, no. 5: 89-99.

Santa Clara County Parks and Recreation Department. 2003. Strategic plan Santa Clara County Parks and Recreation System.

Scanlon, Hugh. 2007. Progression and behavior of the Canoe fire in coast redwood. USDA Forest Service Gen. Tech. Rep. PSW-GTR 194.

Soil Conservation Service. 1980. Soil survey of Santa Cruz County. Soil Conservation Service. United States Department of Agriculture.

Sousa, Wayne P. 1984. The role of disturbance in natural communities. Annual Review of Ecology and Systematics 15: 353-391. 
Squires, Jennifer. 2008. Bonny Doon residents return home as fire nears containment. Santa Cruz Sentinel, June 6, 2008.

Stein, William L. 1990. California-laurel (Umbellularia californica (Hook. \& Am.) Nutt.). In Silvics of North America: 1. Conifers, 2. Hardwoods, Agricultural Handbook 654 ed. Russell M. Burns and Barbara H. Honkala, tech. coords., 2. Washington D.C.: U.S. Department of Agriculture, Forest Service.

Stephens, S. L., R. E. Martin, and N. E. Clinton. 2007. Prehistoric fire area and emissions from California's forests, woodlands, shrublands, and grasslands. Forest Ecology and Management 251, no. 3: 205-216.

Stephens, Scott L. and Danny L. Fry. 2005. Fire histroy in coast redwood stands in the northeastern Santa Cruz Mountains, CA. Fire Ecology 1, no. 1: 2-19.

Stuart, John D. and John O. Sawyer. 2001. Trees and shrubs of California. Ed Phyllis M. Faber and Bruce M. Pavlik. California Natural History Guides. Berkeley: University of California Press.

Sullivan, Thomas P. 1979. Repopulation of clear-cut habitat and conifer seed predation. Journal of Wildlife Management 43, no. 4: 861-871.

Swanton Pacifc Ranch draft management plan. 2004. California Polytechnic State University, San Luis Obispo.

Swanton Pacific Ranch nonindustrial timber management plan. 2007. California Polytechnic University, San Luis Obispo.

Tappeiner, John C., Philip M. McDonald, and Douglas F. Roy. 1990. Lithocarpus densiflorus (Hook. \& Arn.) Rehd.: Tanoak. In Silvics of North America: 1. Conifers, 2. Hardwoods, Agricultural Handbook 654., ed. Russell M. Burns and Barbara H. Honkala, tech. coords., 2:877. Washington D.C.: U.S. Department of Agriculture, Forest Service.

Thornburgh, Dale A. 1990. Quercus chrysolepis Liebm. canyon live oak. In Silvics of North America: 1. Conifers, 2. Hardwoods, Agricultural Handbook 654., ed. Russell M. Burns and Barbara H. Honkala, tech. coords., 2:877. Washington D.C: U.S. Department of Agriculture, Forest Service.

Waring, K. M. and K. L. O'Hara. 2008. Redwood/tanoak stand development and response to tanoak mortality caused by Phytophthora ramorum. Forest Ecology and Management 255, no. 7: 2650-2658. 
White, Peter S. 1979. Pattern, process, and natural disturbance in vegetation. Botanical Review 45, no. 3: 229-299.

Willett, Terrence R. 2001. Spiders and other arthropods as indicators in old-growth versus logged redwood stands. Restoration Ecology 9: 410-420.

Zwolak, Rafal, Dean E. Pearson, Yvette K. Ortega, and Elizabeth E. Crone. 2010. Fire and mice: Seed predation moderates fire's influence on conifer recruitment. Ecology 91, no. 4: 1124-1131. 